Article

\title{
Evaluation of Zeolite as a Potential Reactive Medium in a Permeable Reactive Barrier (PRB): Batch and Column Studies
}

\author{
Liana Carolina Carvalho Rocha * $*$ and Lazaro Valentin Zuquette \\ São Carlos School of Engineering, University of São Paulo, São Carlos, SP, 13566-590, Brazil; lazarus1@sc.usp.br \\ * Correspondence: lianaccr@usp.br; Tel.: +55-16-3373-9501
}

Received: 7 November 2019; Accepted: 28 January 2020; Published: 4 February 2020

check for updates

\begin{abstract}
The purpose of this work is to evaluate the capacity of a natural zeolite to be used as a reactive material in a permeable reactive barrier (PRB) to remove inorganic contaminants from groundwater. To this aim, zeolite samples were subjected to characterization tests, column experiments, batch tests and a flushing process to evaluate the adsorption and desorption capacities of the zeolite. In the column experiments, the samples were subjected to eight successive cycles involving the percolation of a potassium aqueous solution $(1500 \mathrm{mg} / \mathrm{L})$ and a subsequent flushing process with water. Batch tests were conducted by mixing $20 \mathrm{~g}$ of zeolite with $100 \mathrm{~mL}$ of single-element aqueous solutions of $\mathrm{K}$ and $\mathrm{Zn}$ with concentrations of $200 \mathrm{mg} / \mathrm{L}$. The results indicate that the zeolite rock is composed predominantly of clinoptilolite species and has a $\mathrm{Si} / \mathrm{Al}$ ratio of 6.8 , a high cationic exchange capacity (CEC) of $180 \mathrm{cmol}_{\mathrm{c}} / \mathrm{kg}$ and a high $\mathrm{K}^{+}$adsorption rate with a removal efficiency of $78 \%$. The adsorption isotherms of the zeolite follow the Langmuir model and are well fit by a pseudo-second-order kinetic model showing a high correlation coefficient $\left(\mathrm{r}^{2}>0.999\right)$ for both $\mathrm{K}^{+}$ and $\mathrm{Zn}^{2+}$ cations. Additionally, the contaminant transport parameters for $\mathrm{K}^{+}$ions $\left(\mathrm{R}_{\mathrm{d}}=24.9 ; \mathrm{D}_{\mathrm{h}}\right.$ $=1.32 \times 10^{-2} \mathrm{~cm}^{2} / \mathrm{s}$ and $\left.\alpha=1.42\right)$ reveal that the zeolite is resistant to the dispersion of ions in the barrier, indicating that the material has advantageous characteristics for use in a PRB. However, the flushing process of the material is not efficient, indicating that the appropriate use of the zeolite is in clean-up systems in which the adsorbent material can be exchanged after losing its efficiency as a reactive barrier.
\end{abstract}

Keywords: PRB; clinoptilolite; laboratorial tests; adsorption isotherm; kinetic model

\section{Introduction}

Industrial and human activities have generated wastes composed of different chemical compounds that can contaminate environmental compartments, such as groundwater. Such contamination can affect the availability of water for human use and for environmental functions [1-3]. The focus on this type of contamination is constantly increasing because groundwater is the main water source in several parts of the world [4]. Potassium (K) is a component of chemical fertilizers that is abundantly used to enhance crop growth and can be a water pollutant in agriculture [5]. In areas with high water tables and soils and rocks with limited capacity to retain cations, potassium leaches through the soil, contributing to the input of it to groundwater and frequently with silting and eutrophication of freshwater systems [6,7]. Moreover, the dissolution of potassium-rich clay minerals can also release potassium, elevating the concentration of this element in groundwater [8].

Another chemical element commonly present in the environment is zinc ( $\mathrm{Zn})$, which is released by several anthropogenic sources, such as food production, agricultural activities (e.g., liming, sewage sludge, use of organic pesticides), galvanizing and production of ceramics, batteries, deodorants, 
etc. [9]. At high levels, the presence of $\mathrm{Zn}$ has negative effects on not only the environment but also poses a threat to human health [10]. This scenario has encouraged research and the development of new technologies for groundwater clean-up that are more inexpensive and efficient than traditional techniques, such as pump-and-treat, electrochemical/electrokinetic recovery, soil flushing, vitrification and nanotechnology applications that involve excavation and removal of contaminated soils [11].

The removal or attenuation of contaminants in groundwater can involve physicochemical (e.g., dilution, adsorption and precipitation) and degradation processes [12,13]. Adsorption mechanisms require a suitable adsorbent material with a high removal capacity [14]. Normally, the materials chosen for such applications are those with a high degree of porosity, high cationic exchange capacity (CEC), specific surface area, environmental capability, availability and cost-effectiveness [15,16]. Additionally, to be economically advantageous, the material must have low economic value. Therefore, natural materials have been investigated for use in this purpose. The advantages of using natural materials for groundwater clean-up are the low cost and the potential to remove multiple contaminants [17].

Currently, special attention is given to the potential for regeneration or clean-up of the adsorbent material with the objective of reusing the material and reducing the need for a sanitary landfill for disposal or protected places for storage [18]. Diverse processes have been developed for this purpose, such as the use of chloride solutions (e.g., $\mathrm{NaCl}$ ), flushing and phytoremediation processes, and others. However, the regeneration of the adsorbent material should not be too costly; otherwise, the process becomes unfeasible [19].

Groundwater clean-up systems can be a combination of physical barriers associated with chemical properties (capacity of adsorption) or a permeable and reactive barrier (PRB). A PRB is normally used for a not very large contamination plume associated with specific water flow conditions and depths generally less than $20 \mathrm{~m}$. The design of the system must be a combination of natural geological conditions and an adsorbent with certain physicochemical characteristics allowing water to percolate through the pores of the solid material. Furthermore, the design must also permit contact between contaminated water and the adsorbent for a suitable residence time that is long enough for the adsorption process to occur $[20,21]$. The efficiency of a PRB is a direct function of the reactive material characteristics, the thickness of the barrier, the residence time and the effective performance for the removal of contaminants [22].

Several types of reactive materials (natural and industrial) with different sorption characteristics have proven to be efficient in PRBs in terms of the removal of different groups of contaminants present in groundwater. Such materials include (1) modified natural materials, such as brown coal [23], modified montmorillonite [24], modified and treated zeolites [12,25] and zero-valent iron [26]; (2) natural materials, such as zeolites [27-29], limestones [30], laterites [13] and sericite [31]; and (3) combined materials, such as sand and zeolite $[32,33]$ and zero-valent iron and zeolite $[14,20]$.

The type of adsorbent material and the treatment system that should be used depend on the contaminant types that need to be removed, their concentrations and the removal capacity of the system. Considering the set of possible adsorbent materials, zeolites have been studied more intensely than other materials [34]. In recent years, research on the interactions between contaminated water and zeolite has been of great interest for the application of zeolites as catalysts and adsorbents $[35,36]$ because the chemical and physical properties of natural zeolites are advantageous for the retention of different chemical compounds, including heavy metals [37-39], and because zeolites have low economic value. The three-dimensional framework of zeolites contains large central cavities and channels, which can selectively exchange cations and water [40-42], which is why zeolites have been referred to as "molecular sieves" [43].

Clinoptilolite is one of the predominant natural species of zeolites and has been successfully used for contaminant removal $[15,44]$. This mineral belongs to the heulandite group and comprises a two-dimensional channel system (a 10-ring system $(0.31 \mathrm{~nm} \times 0.75 \mathrm{~nm})$, an 8-ring system $(0.36 \mathrm{~nm} \times 0.46 \mathrm{~nm})$ and channels $(0.28 \mathrm{~nm} \times 0.47 \mathrm{~nm})$ [45]. In general, the adsorption process of zeolite comprises six distinct phases: (1) transport of solutes in the soil solution; (2) transport through 
the film surrounding the solid-liquid interface; (3) transport of solutes to micropores; (4) diffusion of solutes on the surface of the solid; (5) diffusion of solutes in clogged micropores; and (6) diffusion in the solid particle [46].

Several other factors influence the adsorption capacity and the selectivity exhibited by zeolite. For example, the original composition of exchangeable cations $(\mathrm{Ca}, \mathrm{Mg}, \mathrm{Na}$ and $\mathrm{K})$ present in zeolite minerals can influence the access of cations to the zeolite structure. Clogging of pores, a result of the accumulation of fine particles on the zeolite surface must also be taken into account since this process prevents access of the elements to the structure, affecting the adsorption process $[47,48]$. There are also factors related to the contaminant solution $(\mathrm{pH}$, temperature and ion concentration) that directly interfere in the adsorption process.

This work presents the results of a study carried out to evaluate the adsorption and desorption capacities of a zeolite for use as a reactive medium in a PRB for the clean-up of contaminated groundwater and industrial residual water with inorganic contaminants. This study involved column and batch experiments considering different adsorption conditions, volumetric arrangements of particles and desorption reactions by a flushing process.

\section{Materials and Methods}

\subsection{Materials}

The zeolite material is from the Tasajeras sedimentary deposit (Cuba). Natural rock samples containing between $85 \%$ and $97 \%$ of zeolite [49] were crushed and subjected to processes for separation of other minerals such as montmorillonites, calcites and iron compounds. Thus, the study material is constituted of more than $90 \%$ of the zeolites associated to certain quartz and feldspars. The study material is in natural conditions without any chemical modifications and/or treatments. Samples were divided into three particle size groups: 0.4 to $1.0 \mathrm{~mm}, 1.0$ to $2.0 \mathrm{~mm}$ and 1.0 to $3.0 \mathrm{~mm}$.

\subsection{Characterization of the Zeolite}

Samples of the zeolite were subjected to particle size analysis according to the methods recommended by the Brazilian Association of Technical Standards (ABNT) [50]. The determination of the specific weight of solids $\left(\gamma_{\mathrm{s}}\right)$ was carried out according to the pycnometer method [51], and the apparent specific dry weight $\left(\gamma_{\mathrm{d}}\right)$ was obtained through maximum and minimum void index tests, which were performed based on the standards of ABNT [52,53]. The $\gamma_{d}$ was obtained individually for all considered arrangements of particles.

\subsection{Mineralogical Characterization}

Mineralogical analysis was carried out using 2 methods. Powder X-ray diffraction (XRD) was performed with a Rigaku Rotaflex diffractometer $(\mathrm{Cu} \mathrm{K} \alpha)$ model RU200B with an X-ray generator operated at $40 \mathrm{kV}$ and $30 \mathrm{~mA}$. During measurements, the angular range from $3^{\circ}$ to $120^{\circ}$ with a $0.02^{\circ}$ step size was considered. The phase contents in the samples were determined by calculating the ratio of the sum of the intensities of the eight most intense peaks. Second, the zeolite samples were also subjected to scanning electron microscopy (SEM) coupled with energy-dispersive X-ray spectroscopy (EDX) analysis for structural characterization. SEM images were recorded with a ZEISS LEO 440, model 7060 , operating with a $15 \mathrm{kV}$ electron beam, a current of $2.82 \mathrm{~A}$ and probe current of $200 \mathrm{pA}$. The EDX analyses utilized EDX LINK ANALYTICAL equipment, an Isis System Series 300, a SiLiPentafet detector, and an ATW II (Atmosphere Thin Window), with a resolution of $133 \mathrm{eV}$ at $5.9 \mathrm{keV}$ and an area of $10 \mathrm{~mm}^{2}$ square, coupled to a ZEISS LEO 440 electron microscope.

\subsection{Physicochemical and Chemical Characterization}

The chemical composition of the zeolite was analyzed by X-ray fluorescence (XRF) analysis and laser-induced breakdown spectroscopy (LIBS), also known as laser-induced plasma spectroscopy 
(LIPS). The (CEC) was obtained in 2 forms: total and external. The total CEC procedure utilized was initially described by Chapman et al. [54] and was also used by Choo et al. and Zhou et al. [55,56]. First, the zeolite samples were subjected to successive saturation with a solution of ammonium ions $\left(\mathrm{NH}_{4}{ }^{+}\right.$ $2 \mathrm{~mol} / \mathrm{L})$ for the determination of exchangeable bases $\left(\mathrm{Na}^{+}, \mathrm{K}^{+}, \mathrm{Ca}^{2+}\right.$ and $\left.\mathrm{Mg}^{2+}\right)$. Then, the obtained samples were further treated with $\mathrm{K}^{+}$ion solution $(2 \mathrm{~mol} / \mathrm{L})$, and the content of $\mathrm{NH}_{4}{ }^{+}$remaining in the zeolite was determined from the solution. The $\mathrm{K}^{+}$ions were measured using a Micronal flame photometer model B26, and the exchangeable bases were determined by atomic absorption spectrophotometry. The $\mathrm{NH}_{4}{ }^{+}$ions were measured using an $\mathrm{NH}_{3}$ selective electrode from METROHM, AG. The external CEC of the zeolite samples was determined by the methylene blue adsorption method according to the methodology described by Pejon [57]. Methylene blue consists of an organic dye that dissociates into chloride and methylene blue cation $\left(\mathrm{C}_{16} \mathrm{H}_{18} \mathrm{~N}_{3} \mathrm{~S}^{+}\right)$in an aqueous solution. To evaluate the influence of particle size on the external CEC, methylene blue adsorption was performed for different particle size ranges: $<0.074 \mathrm{~mm}$ (the fraction passing the No. 200 sieve), 0.4 to $1.0 \mathrm{~mm}, 1.0$ to $2.0 \mathrm{~mm}$ and 1.0 to $3.0 \mathrm{~mm}$. The external CEC was calculated using Equation (1) as follows:

$$
C E C=\frac{V \times C \times 100}{M}
$$

where $V$ is the volume of the methylene blue solution used (L); $C$ is the concentration of the methylene blue solution in normality $(\mathrm{N})$; and $M$ is the dry zeolite mass (g).

\subsection{Batch Studies}

To assess the adsorption capacity of zeolite samples with respect to different ions, zeolite particles with sizes of 1.0 to $2.0 \mathrm{~mm}$ were subjected to reaction with single-element aqueous solutions of $\mathrm{K}^{+}$and $\mathrm{Zn}^{2+}$ with concentrations of $200 \mathrm{mg} / \mathrm{L}$. The solutions of $\mathrm{K}^{+}$and $\mathrm{Zn}^{2+}$ were obtained from dissolution of $\mathrm{KCl}$ and $\mathrm{ZnCl}_{2}$, respectively. The choice to use this particle size was based on the results of the $\gamma_{\mathrm{d}}$ and hydraulic conductivity tests.

The test procedure consisted of placing $20 \mathrm{~g}$ of zeolite in a beaker and adding $100 \mathrm{~mL}$ of $\mathrm{K}^{+}$ aqueous solution (one-step batch test). Aliquots were collected at each predetermined interval (i.e., each hour during the first eight hours and then after 12, 24 and $48 \mathrm{~h}$ of test duration). This same procedure was performed with the $\mathrm{Zn}^{2+}$ solution.

The zeolite samples were also submitted to kinetic batch tests [58]. The experimental procedure consisted of placing $2.5 \mathrm{~g}$ of zeolite particles in a receptacle and then adding $50 \mathrm{~mL}$ of $\mathrm{K}^{+}$ion solutions with different concentrations in the range of 500 to $5000 \mathrm{mg} / \mathrm{L}$. Similarly, aliquots were collected at predetermined intervals. The temperature was maintained at a constant value of $21 \pm 2{ }^{\circ} \mathrm{C}$ during this experiment. All the tests were performed in triplicate. The data obtained were fitted by adsorption isotherms and kinetic models. Due to the number of experiments and the amount of data obtained, the kinetic batch test was performed with only $\mathrm{K}^{+}$solutions. To evaluate the effects of adsorption process in the structure of the material, the zeolites samples were submitted to chemical characterization after adsorption.

\subsection{Column Experiments}

Columns with a diameter of $98 \mathrm{~mm}$ and length of $152 \mathrm{~mm}$ were filled with a mean amount of $1.2 \mathrm{~kg}$ of zeolite particles in the size range of 1.0 to $2.0 \mathrm{~mm}$. The columns were subjected to percolation of a $\mathrm{K}^{+}$ ion solution $(1500 \mathrm{mg} / \mathrm{L})$. A float ball was used to maintain a low hydraulic gradient (approximately 1 ) to ensure that the contact between the solution and the zeolite was long enough for chemical reactions to occur. The solution passed through the column from the top downward at a constant flow rate $\left(4.61 \times 10^{-5} \mathrm{~m} / \mathrm{s}\right)$. The adsorption process was monitored by taking small aliquots from the column outlet for each pore volume percolated. The results were obtained by plotting breakthrough curves of $C / C_{0}$ versus the number of percolated pore volumes (Equation (2)), where $C_{0}$ is the input solution concentration $(\mathrm{mg} / \mathrm{L})$ and $\mathrm{C}$ is the outlet solution concentration $(\mathrm{mg} / \mathrm{L})$. The experiment was performed 
at a constant temperature of $21 \pm 2{ }^{\circ} \mathrm{C}$, and the $\mathrm{pH}$ and electrical conductivity (CE) values were recorded using an HI 1131 Digimed electrode and a 7A04 CE Analyser, respectively.

$$
P V=\frac{Q t}{A L n}
$$

where $P V$ is pore volume; $Q$ is the flow rate in the column; $t$ is the time; $A$ is the cross-sectional area of the soil column; $L$ is the column length and $n$ is the total porosity.

The breakthrough curves were also utilized to determine the retardation factor $\left(R_{d}\right)$, which represents the resistance of the solid in the mass transfer process, and the hydrodynamic dispersion coefficient $\left(D_{h}\right)$, which describes the mixing processes of a solute in porous media, according to the methodology proposed by Shackelford $[59,60]$.

\subsection{Flushing Procedure}

After submitted to the percolation with $\mathrm{K}^{+}$solution, the column of zeolite was subjected to a flushing process consisting of water percolation through the column. The goal of this procedure was to assess the ability of the zeolite particles to desorb ions with a flow of natural solution as water, so as to avoid introducing a new element into the environment and consequently, to contaminate the area with a new chemical product. In this study, the process of percolating the contaminant solution and the subsequent flushing in the column is called a cycle. The percolation of the $\mathrm{K}^{+}$solution in the column lasted until the outflow reached the initial concentration $\left(C=C_{0}\right)$. Similarly, the flushing process ended when the input and output solutions came into equilibrium. In both stages, after reaching equilibrium, the experiment was continued for another 20 pore volumes to observe possible changes and different behaviors. Similarly, this test was conducted while monitoring the temperature and physicochemical variables ( $\mathrm{pH}$ and $\mathrm{CE}$ ). The columns were subjected to eight successive cycles.

An additional test was also developed to complement the flushing process. The test procedure was conducted using $20 \mathrm{~g}$ of zeolite in contact with a $\mathrm{K}^{+}$aqueous solution $(1500 \mathrm{mg} / \mathrm{L})$ in a beaker until the concentration of the solution stabilized. After reaching equilibrium, the zeolite was placed in contact with water (with a pH between 6.8 and 7.2 and an EC of $2.48 \mu \mathrm{S}$ ) in another beaker for enough time to stabilize the concentration of $\mathrm{K}^{+}$ions in the water solution. The concentration of $\mathrm{K}^{+}$cations and residence time were monitored throughout the experiment to assess the desorption capacity of the zeolite.

\section{Results and Discussion}

\subsection{Basic Characterization of the Zeolite}

The grain-size distribution curves (A, B and C) obtained for the zeolite samples are shown in Figure 1. It can be observed that the material, regardless of the particle size range, can be considered to be well graded, with particles distributed along the entire range. The specific weight of solids $\left(\gamma_{\mathrm{s}}\right)$ shows an average value of $22.87 \mathrm{kN} / \mathrm{m}^{3}$, with a standard deviation of 0.005 . This value is in agreement with the values found in the literature [61], which range from 22.0 to $24.0 \mathrm{kN} / \mathrm{m}^{3}$. The values of specific apparent dry weight $\left(\gamma_{\mathrm{d}}\right)$ related to the range of maximum and minimum void ratios were between 10 and $11 \mathrm{kN} / \mathrm{m}^{3}$. The highest value of $\gamma_{\mathrm{d}}$ was found for the smallest particles tested (0.4 to $1.0 \mathrm{~mm}$ ), and the lowest value of $\gamma_{d}$ was found for particles with sizes of 1.0 to $3.0 \mathrm{~mm}$. This difference is because smaller particles tend to achieve a more effective arrangement of the grains. Thus, these results indicate that there are several possibilities for designing barriers with different magnitudes of hydraulic conductivity, thereby providing adaptability to different hydrogeological characteristics. 


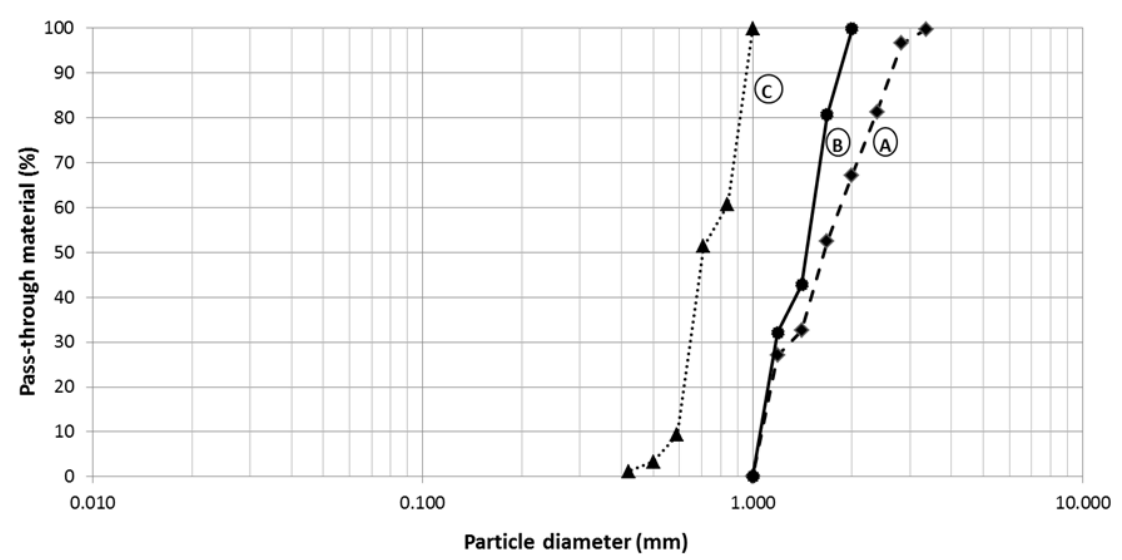

Figure 1. Grain-size distribution curves of zeolite particle size ranges of (A) 1.0-3.0 mm; (B) 1.0-2.0 mm; and (C) $0.4-1.0 \mathrm{~mm}$.

\subsection{Mineralogical and Chemical Characterization}

The results of the XRD analysis of the zeolite are shown in Figure 2. The peak positions at $2 \theta=9.9^{\circ}$ and $22.24^{\circ}$ and the relative intensities observed match well with the clinoptilolite species. Additionally, small amounts of secondary components, such as quartz and feldspar, were also detected in the sample. Rodríguez-Fuentes et al. [62] found a similar composition when analyzing zeolite minerals from the same deposit.

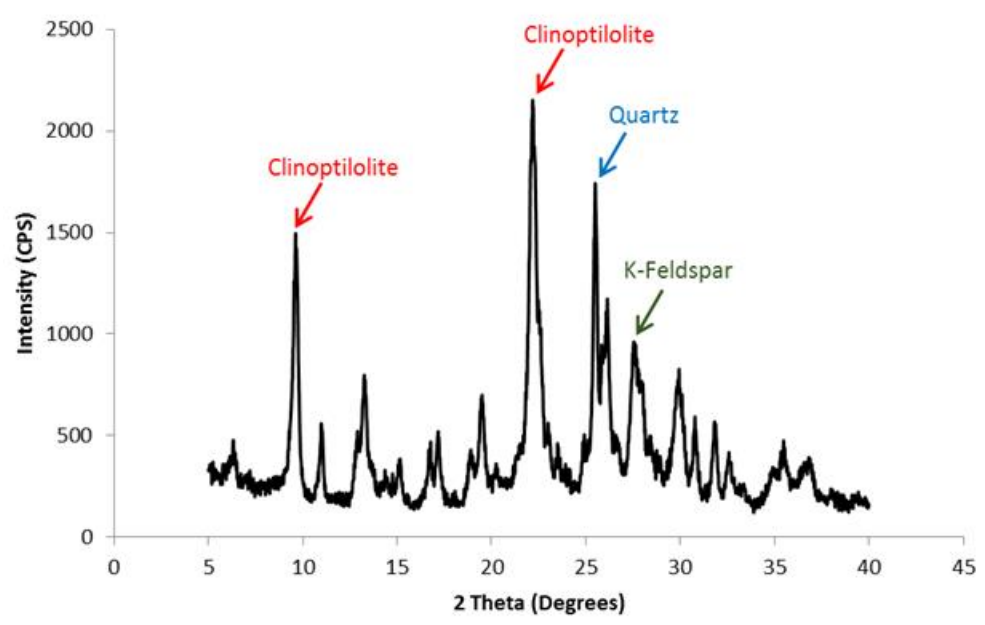

Figure 2. Diffractogram of the zeolite sample.

SEM analysis was performed to analyze the morphology of the zeolite. Figure 3 shows a micrograph of a zeolite particle, which shows a regular surface composed of plates with small voids formed between the particles and amorphous (noncrystalline) materials.

The zeolite samples were also subjected to EDX analysis for semiquantitative determination of the chemical composition of the several features observed in the solid surface. Three areas of the zeolite sample were chosen randomly, as shown in Figure 4. The spectral diagrams obtained for each of the analyzed areas are presented in Figure 5. 


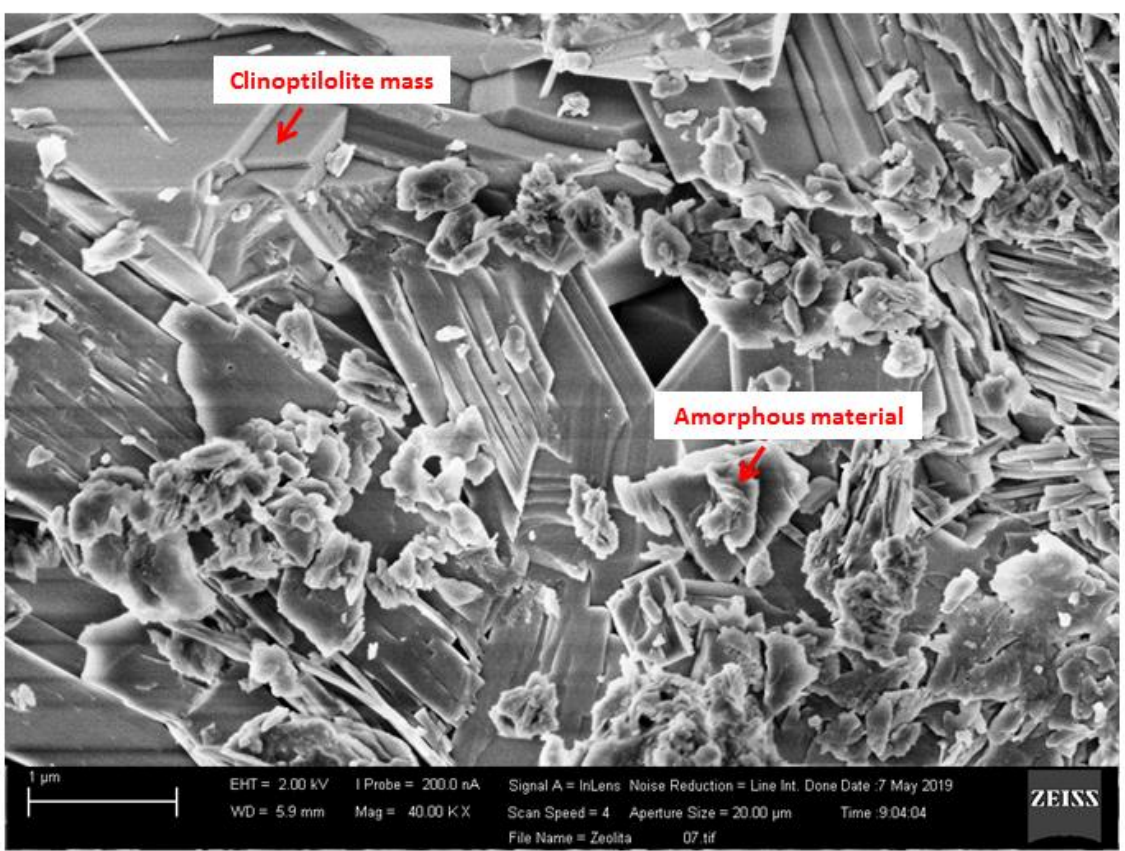

Figure 3. Micrographs of zeolite obtained by SEM analysis.

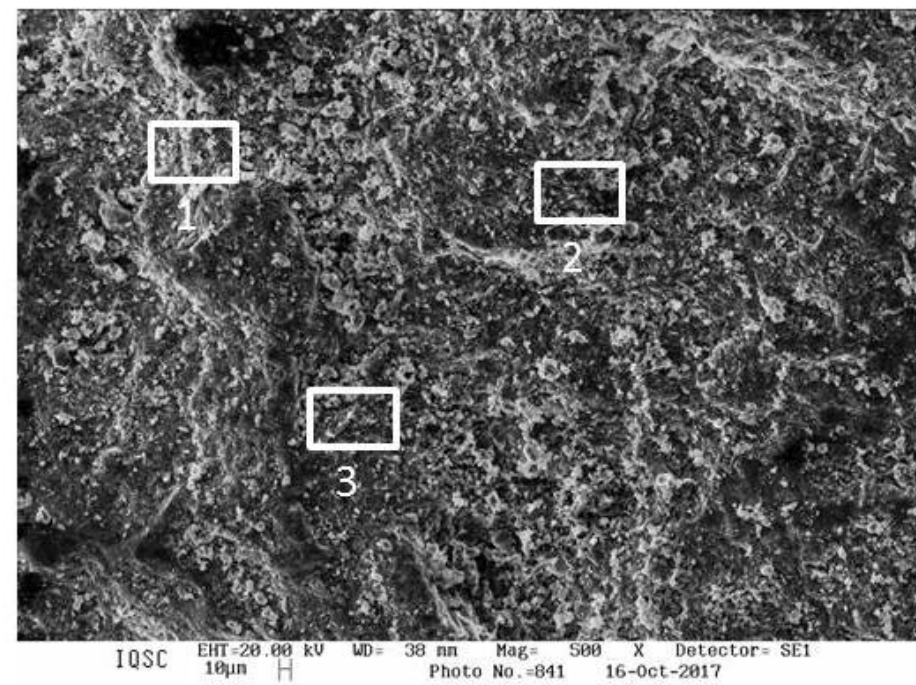

Figure 4. Locations of areas subjected to EDX analyses.

By analyzing the spectral diagrams obtained, it can be concluded that the different areas have similar chemical compounds, indicating that the material has a homogeneous average composition. In addition, the large amounts of $\mathrm{Si}$ and $\mathrm{Al}$ observed in these diagrams, associated with lower amounts of $\mathrm{Ca}, \mathrm{K}, \mathrm{Mg}, \mathrm{Fe}$ and $\mathrm{Ti}$, reveals that the fundamental composition is similar to that of clinoptilolite, which is consistent with the data obtained from the XRF analysis. These data are summarized in Table 1. 


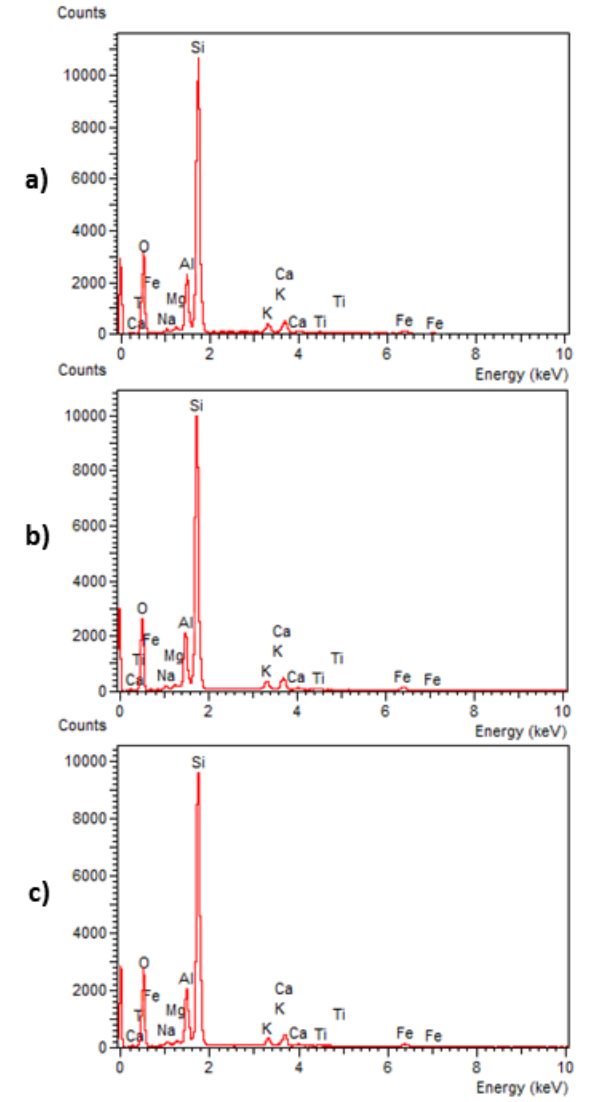

Figure 5. Spectral diagrams of (a) area 1; (b) area 2; (c) area 3.

Table 1. Chemical composition of the zeolite sample by XRF analysis.

\begin{tabular}{ccc}
\hline Oxides & Mass/Mass (\%) & Standard Deviation (\%) \\
\hline $\mathrm{MgO}$ & 0.715 & 0.081 \\
$\mathrm{Al}_{2} \mathrm{O}_{3}$ & 10.107 & 0.025 \\
$\mathrm{SiO}_{2}$ & 79.280 & 0.185 \\
$\mathrm{~K}_{2} \mathrm{O}$ & 2.083 & 0.014 \\
$\mathrm{CaO}$ & 4.564 & 0.052 \\
$\mathrm{TiO}_{2}$ & 0.418 & 0.008 \\
$\mathrm{Fe}_{2} \mathrm{O}_{3}$ & 2.676 & 0.052 \\
$\mathrm{ZnO}$ & 0.010 & 0.001 \\
$\mathrm{BaO}$ & 0.147 & 0.002 \\
$\mathrm{Si} / \mathrm{Al}$ & 6.8 & 0.126 \\
\hline
\end{tabular}

The XRF results show that the fundamental composition of the clinoptilolite comprises silicon, aluminum and oxygen ions, in addition to $\mathrm{Mg}, \mathrm{K}, \mathrm{Ca}, \mathrm{Ti}, \mathrm{Fe}, \mathrm{Zn}$ and $\mathrm{Ba}$ ions. $\mathrm{Ca}, \mathrm{Mg}$ and $\mathrm{K}$ are called exchangeable ions. The $\mathrm{Si} / \mathrm{Al}$ ratio was determined to be 6.8. This value is in accordance with the values described by the Subcommittee on Zeolites of the International Mineralogical Association, which adopted the relation of $\mathrm{Si} / \mathrm{Al} \geq 4.0$ for clinoptilolite species [63]. In general, the $\mathrm{Si} / \mathrm{Al}$ ratio is an important property of zeolites because it is theoretically related to the CEC and selectivity of this material. The lower the $\mathrm{Si} / \mathrm{Al}$ ratio is, the higher the CEC observed for zeolite [27]; similarly, zeolite with a high aluminum concentration has a preference for small or highly charged cations, such as cadmium and lead [64].

The result of the LIBS is shown in Figure 6. The presence of the same chemical elements found by the other techniques used to determine the chemical composition of the zeolite samples was 
confirmed by this test. However, the presence of sodium ( $\mathrm{Na}$ ), which had not been detected by the other experiments, was also observed. The Na peak could be related to either the actual presence of $\mathrm{Na}_{2} \mathrm{O}$ in the samples, because of the volcanism activity that gives origin to zeolite-bearing rocks in $\mathrm{Cuba}$, as the LIBS equipment is very sensitive to $\mathrm{Na}$, or to some external interference, such as hand contact or other factors, resulting in the detection of this element in the LIBS analysis.

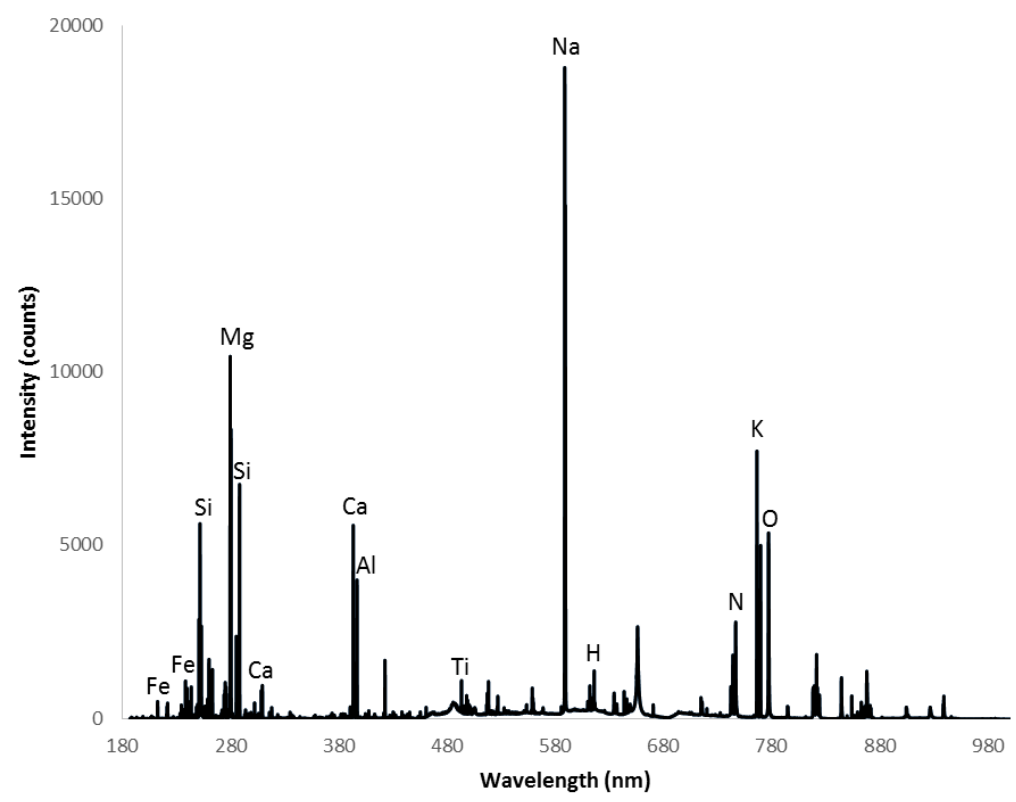

Figure 6. Spectroscopy obtained by laser-induced plasma spectroscopy analysis.

It is worth mentioning that elements may have more than one characteristic wavelength; therefore, some of the elements demonstrated in the above spectroscopy analysis may appear more than once. This fact is not related to the quantity but only to the presence of these elements. However, the peak intensity is related to the proportion, and the peak intensity results also agree with the data obtained by other techniques.

\subsection{Batch Studies}

The value of the total CEC of the studied zeolite obtained by successive ammonium saturation was $180 \mathrm{cmol}_{\mathrm{c}} / \mathrm{kg}$. This result is in agreement with the CEC values found by Oliveira [65], who obtained a CEC value of $152 \mathrm{cmol}_{\mathrm{C}} / \mathrm{kg}$ for the same species. In addition, this is within the range of the CEC values reported in the literature for the zeolite clinoptilolite of approximately $230 \mathrm{cmol}_{\mathrm{c}} / \mathrm{kg}$ [66] and $122 \mathrm{cmol}_{\mathrm{C}} / \mathrm{kg}$ [28].

The CEC is mainly related to the imbalance in surface charges that attracts cations to maintain overall neutral conditions. The $\mathrm{CEC}$ of zeolite is a function of the $\mathrm{Si} / \mathrm{Al}$ ratio and is expressed in the number of cations per unit mass or volume available for the CEC [28]. The adsorption capacity of zeolite is not only associated with the CEC but is also controlled by the size and shape of the voids; the size of the adsorbed molecules; the size, number and positions of the exchangeable cations that compensate for the anionic load; and the presence of structural defects. In addition to these factors, the adsorbent particle size also influences the final adsorption capacity [67]. The external CEC values of zeolite determined by the methylene blue adsorption method were $2 \mathrm{cmol}_{\mathrm{c}} / \mathrm{kg}$ for the particle size range of 1.0 to $3.0 \mathrm{~mm} ; 9 \mathrm{cmol}_{\mathrm{c}} / \mathrm{kg}$ for the particle size range of 0.4 to $1.0 \mathrm{~mm}$; and $18 \mathrm{cmol}_{\mathrm{C}} / \mathrm{kg}$ for the particle size less than $0.074 \mathrm{~mm}$. This pattern occurs because, in the same volume of material, smaller particles are in greater quantity; that is, a larger external area is available for reactions to occur, resulting in a greater external adsorption capacity for the smallest particles. 
The adsorption capacity curves of clinoptilolite for single-element aqueous solutions of $\mathrm{K}^{+}$and $\mathrm{Zn}^{2+}$ from the first test (one-step batch test) are shown in Figure 7. The curves were formed by the mean values of adsorption capacity versus time obtained for the triplicates, for which the standard deviation values were 0.057 to $\mathrm{K}^{+}$adsorption and 0.074 to $\mathrm{Zn}^{2+}$ reactions. In general, the zeolite adsorption process for both ions can be divided in two distinct parts. The first part corresponds to the initial hours of the experiment, where the adsorption process is very fast. In the second part, adsorption continues to occur, but at a slower rate. This behavior is explained by the fact that at the beginning of the exchange process, most of the zeolite adsorption sites are available; however, as the process develops, these sites become occupied, making them difficult to access and causing a repulsion effect between the adsorbed ions and the remaining ions in solution [68]. Comparing the curves obtained for both analyzed ions, it can be concluded that $\mathrm{Zn}^{2+}$ adsorption is slower than $\mathrm{K}^{+}$ adsorption. This pattern is linked to the fact that the zeolite presents preferential adsorption for ions with lower hydration energy and, consequently, a smaller hydrated ionic radius, which would explain the lower affinity found for $\mathrm{Zn}^{2+}$ [69]. Additionally, the $\mathrm{K}^{+}$exerts a high polarizing power than $\mathrm{Zn}^{2+}$ on the zeolite structure, which explains the strong influence of $\mathrm{K}^{+}$in the zeolite frame and the low mobility of $\mathrm{Zn}^{2+}$ cation.

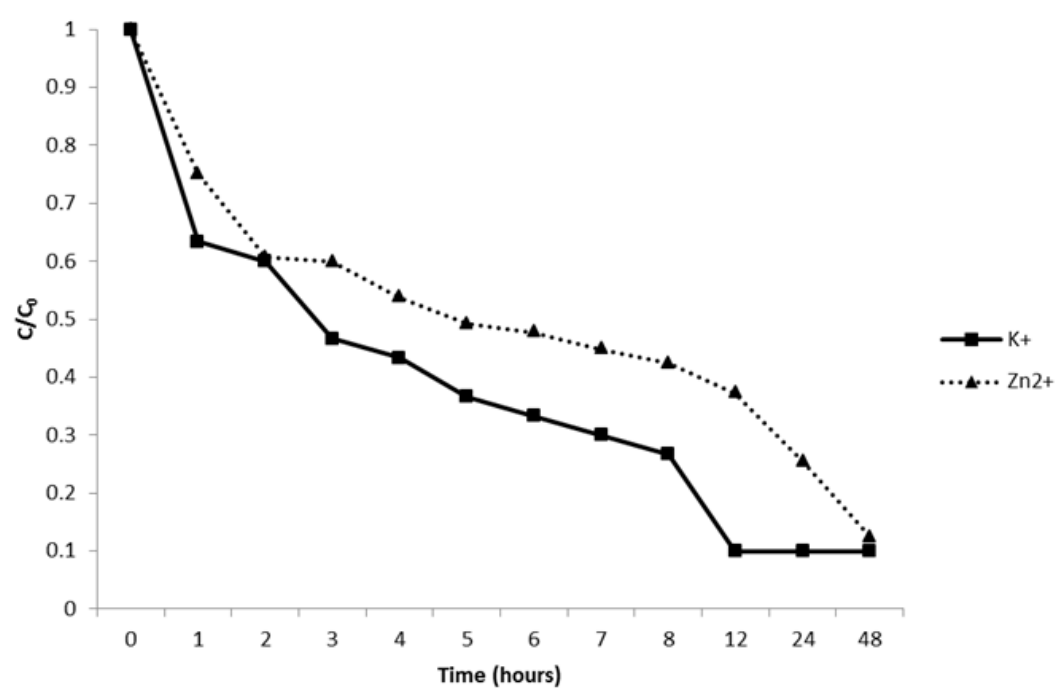

Figure 7. Adsorption capacity of the zeolite for $\mathrm{K}^{+}$and $\mathrm{Zn}^{2+}$ cations obtained from one-step batch test analysis.

The adsorption isotherm for $\mathrm{K}^{+}$on clinoptilolite obtained from the kinetic batch test is shown in Figure 8a. The standard deviation obtained with the triplicate samples was 0.065 . A convex shape of the adsorption isotherm compatible with the Langmuir model was observed, fitting the " $\mathrm{L}$ " type isotherms according to the classification of Giles et al. [70]. Due to the shape of the curve, the adsorption isotherm was adjusted by the Freündlich (Equation (3)) and Langmuir (Equation (4)) models, as shown in Figure 8 b,c, respectively. The Sips model was also tested, but when applied, the adjustment yielded similar results to the ones obtained by the Langmuir model because the Sips model is a combination of Freündlich and Langmuir adsorption isotherms. Thus, when applied to materials with homogeneous binding sites $\left(n_{S}=1\right)$, the Sips Equation is reduced to the Langmuir model. The Freündlich model is used to describe a heterogeneous adsorption system in which the reactions can take place at several sorption sites [71], whereas the Langmuir isotherm model assumes that the adsorption of dissolved ions occurs in a monolayer form at specific homogenous sites without interaction with the adsorbed molecules [72]. 


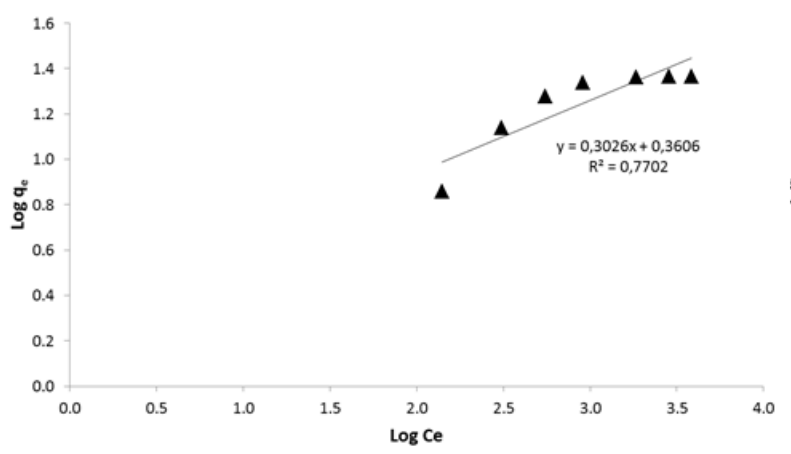

b)
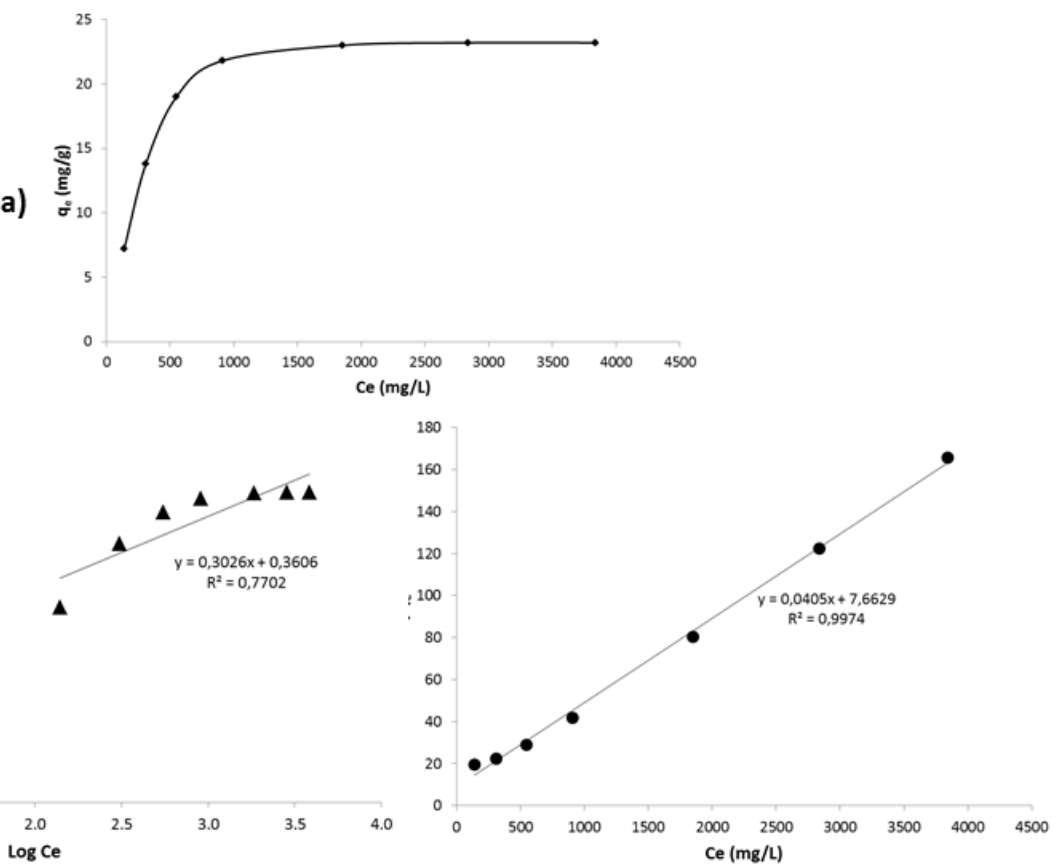

c)

Figure 8. Representative adsorption isotherm obtained by kinetic batch test for $\mathrm{K}^{+}$ions (a) and the adjustment of the adsorption isotherm by Langmuir (b) and Freündlich (c) models.

Freündlich:

$$
q_{e}=K_{F} C_{e}^{1 / n_{F}}
$$

Langmuir:

$$
\mathrm{q}_{\mathrm{e}}=\frac{\alpha \beta \mathrm{C}_{\mathrm{e}}}{1+\alpha \mathrm{C}_{\mathrm{e}}}
$$

where $\mathrm{q}_{\mathrm{e}}$ is the amount of sorbed ion per gram of sorbent at equilibrium ( $\mathrm{mmol} / \mathrm{g}$ ) and Ce is the equilibrium concentration of the solution $(\mathrm{mmol} / \mathrm{L})$. The Freündlich model constants $\mathrm{K}_{\mathrm{F}}$ and $\mathrm{n}_{\mathrm{F}}$ represent the relative capacity and the adsorption intensity, respectively, whereas the Langmuir model constants $\alpha$ and $\beta$ represent the energy of adsorption $(\mathrm{L} / \mathrm{mmol})$ and the maximum adsorption capacity of the sorbent $(\mathrm{mmol} / \mathrm{g})$, respectively.

Through isotherm analysis, it can be concluded that the zeolite has a high $\mathrm{K}^{+}$adsorption capacity, reaching a maximum adsorption of $19.5 \mathrm{mg} / \mathrm{g}$. These data corroborate the values found in the literature for clinoptilolite. Jaskunas et al. [68] analyzed the adsorption capacity of the same zeolite species and obtained a value of $26.2 \mathrm{mg} / \mathrm{g}$ for $\mathrm{K}^{+}$ions. The parameters calculated by the fits of the data to the Freündlich $\left(\mathrm{r}^{2}=0.77\right)$ and Langmuir $\left(\mathrm{r}^{2}=0.99\right)$ models are reported in Table 2 , indicating that the Langmuir model is the best model to represent the adsorption process of $\mathrm{K}^{+}$on clinoptilolite and that similar results were obtained by other authors [68]. The Langmuir model suggests that the adsorption process of $\mathrm{K}^{+}$on clinoptilolite occurs on the surface of the material, which contains a finite number of identical adsorption channels and uniform adsorption energies on the surface. This model also has an essential characteristic that is expressed by a dimensionless constant number called the equilibrium parameter or separation factor $\left(\mathrm{R}_{\mathrm{L}}\right)$. This constant allows evaluation of the adsorption process by the curvature of the isotherm: if $R_{L}=0$, the process is irreversible; if $0<R_{L}<1$, it is favorable; if $R_{L}=1$, it is linear; and if $R_{L}>1$, it is not favorable. As shown in Table 2, the value of $R_{L}$ indicates a favorable adsorption process between the zeolite and $\mathrm{K}^{+}$ions. In general, good adsorbents are those that present a high $\beta$ value and a low adsorption energy $(\alpha)$ [73]. Thus, the results obtained indicate that the zeolite is a good adsorbent for $\mathrm{K}^{+}$ions. 
Table 2. Parameters of the adsorption isotherm fit to the Freündlich and Langmuir models.

\begin{tabular}{|c|c|c|c|c|c|c|}
\hline \multicolumn{3}{|c|}{ Freündlich } & \multicolumn{4}{|c|}{ Langmuir } \\
\hline$K_{F}(1 / g)$ & $\mathbf{N}_{\mathbf{F}}$ & $\mathbf{r}^{2}$ & $A\left(m^{-1}\right)$ & B (mg/g) & $\mathrm{r}^{2}$ & $\mathbf{R}_{\mathrm{L}}$ \\
\hline 1.685 & 3.31 & 0.77 & 0.0053 & 19.50 & 0.99 & 0.54 \\
\hline
\end{tabular}

\subsection{Kinetic Studies}

The data of the batch test are also plotted for kinetic analysis, as shown in Figure 9. The curve parameters obtained by adjustment with the pseudo-first-order (Equation (5)), pseudo-second-order (Equation (6)) and Elovich (Equation (7)) models are summarized in Table 3.

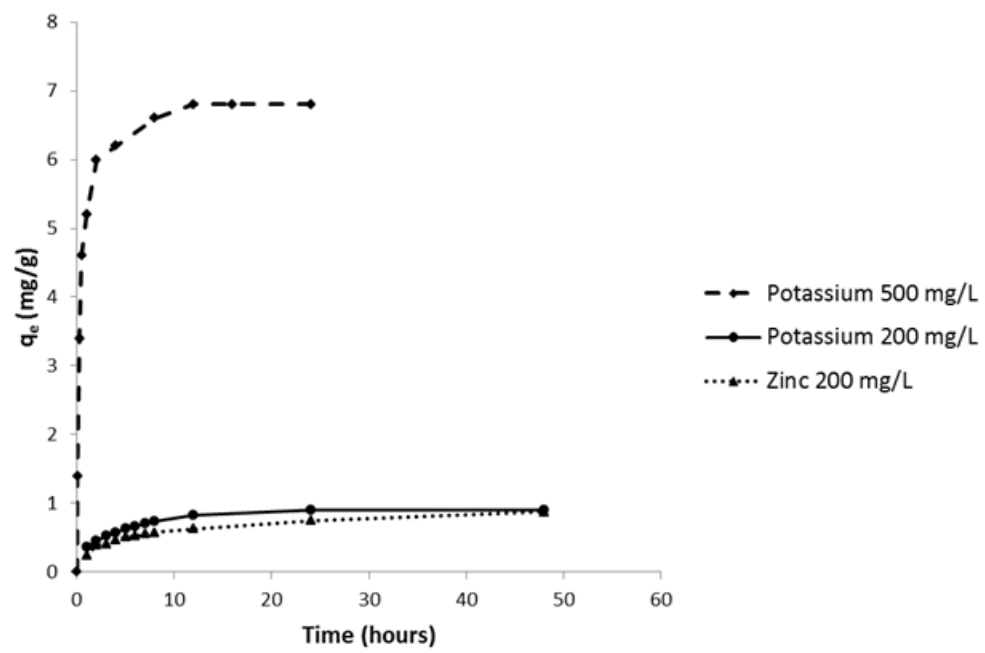

Figure 9. Kinetic adsorption curves of $\mathrm{K}^{+}$and $\mathrm{Zn}^{2+}$ on zeolite.

Table 3. Summary of kinetic parameters according to adjustment models.

\begin{tabular}{|c|c|c|c|c|c|c|c|}
\hline \multirow[b]{2}{*}{$\begin{array}{c}\mathrm{K}^{+} \\
500 \mathrm{mg} / \mathrm{L}\end{array}$} & \multirow{2}{*}{$\begin{array}{c}\mathrm{q}_{\mathrm{e}} \begin{array}{c}\text { Experimental } \\
(\mathrm{mg} / \mathrm{g})\end{array} \\
6.9\end{array}$} & \multicolumn{2}{|c|}{ Pseudo-1st- Order } & \multicolumn{2}{|c|}{ Pseudo-2nd-Order } & \multicolumn{2}{|c|}{ Elovich } \\
\hline & & $\begin{array}{c}\mathrm{q}_{\mathrm{e}}(\mathrm{mg} / \mathrm{g}) \\
\mathrm{k}_{1}\left(\mathrm{~s}^{-1}\right) \\
\mathrm{r}^{2}\end{array}$ & $\begin{array}{l}2.446 \\
0.003 \\
0.789\end{array}$ & $\begin{array}{c}\mathrm{q}_{\mathrm{e}}(\mathrm{mg} / \mathrm{g}) \\
\mathrm{k}_{2}\left(\mathrm{~s}^{-1}\right) \\
\mathrm{r}^{2}\end{array}$ & $\begin{array}{l}6.882 \\
0.009 \\
0.999 \\
\end{array}$ & $\begin{array}{c}\beta(\mathrm{g} / \mathrm{mg}) \\
\alpha(\mathrm{mg} / \mathrm{g} \text { min }) \\
\mathrm{r}^{2}\end{array}$ & $\begin{array}{l}1.026 \\
1.720 \\
0.937\end{array}$ \\
\hline $\begin{array}{c}\mathrm{K}^{+} \\
200 \mathrm{mg} / \mathrm{L}\end{array}$ & 0.9 & $\begin{array}{c}\mathrm{qe}(\mathrm{mg} / \mathrm{g}) \\
\mathrm{k}_{1}\left(\mathrm{~s}^{-1}\right) \\
\mathrm{r}^{2}\end{array}$ & $\begin{array}{l}1.296 \\
0.003 \\
0.970\end{array}$ & $\begin{array}{c}\mathrm{q}_{\mathrm{e}}(\mathrm{mg} / \mathrm{g}) \\
\mathrm{k}_{2}\left(\mathrm{~s}^{-1}\right) \\
\mathrm{r}^{2}\end{array}$ & $\begin{array}{l}0.949 \\
0.008 \\
0.998\end{array}$ & $\begin{array}{c}\beta(\mathrm{g} / \mathrm{mg}) \\
\alpha \underset{(\mathrm{mg} / \mathrm{g} \min )}{\mathrm{r}^{2}}\end{array}$ & $\begin{array}{l}6.350 \\
0.872 \\
0.942\end{array}$ \\
\hline $\begin{array}{c}\mathrm{Zn}^{2+} \\
200 \mathrm{mg} / \mathrm{L}\end{array}$ & 0.87 & $\begin{array}{c}\mathrm{qe}_{\mathrm{e}}(\mathrm{mg} / \mathrm{g}) \\
\mathrm{k}_{1}\left(\mathrm{~s}^{-1}\right) \\
\mathrm{r}^{2}\end{array}$ & $\begin{array}{l}1.696 \\
0.001 \\
0.899\end{array}$ & $\begin{array}{c}\mathrm{q}_{\mathrm{e}}(\mathrm{mg} / \mathrm{g}) \\
\mathrm{k}_{2}\left(\mathrm{~s}^{-1}\right) \\
\mathrm{r}^{2}\end{array}$ & $\begin{array}{l}0.929 \\
0.004 \\
0.993\end{array}$ & $\begin{array}{c}\beta(\mathrm{g} / \mathrm{mg}) \\
\alpha \underset{\mathrm{mg} / \mathrm{g} \cdot \mathrm{min})}{\mathrm{r}^{2}}\end{array}$ & $\begin{array}{l}6.361 \\
1.924 \\
0.992\end{array}$ \\
\hline
\end{tabular}

Pseudo-first-order equation:

$$
\log \left(q_{e}-q_{t}\right)=\log q_{e}-\frac{k_{1} t}{2.303}
$$

where $t$ is the reaction time ( $\mathrm{min}) ; q_{e}(\mathrm{mg} / \mathrm{g})$ and $q_{t}(\mathrm{mg} / \mathrm{g})$ are the amount of adsorbed ion at equilibrium and time $t$, respectively; and $k_{1}\left(\mathrm{~min}^{-1}\right)$ represents the pseudo-first-order adsorption rate constant.

Pseudo-second-order equation:

$$
\frac{1}{q_{t}}=\frac{1}{k_{2} q_{e}^{2}}+\frac{1}{q_{e}}
$$


where $q_{e}(\mathrm{mg} / \mathrm{g})$ and $q_{t}(\mathrm{mg} / \mathrm{g})$ represent the amount of adsorbed ion at equilibrium and at time $t$, respectively, and $k_{2}\left(\mathrm{~min}^{-1}\right)$ is the pseudo-second-order rate constant.

Elovich equation:

$$
q_{t}=\frac{1}{\beta} \ln (t)+\frac{1}{\beta} \ln (\alpha \beta)
$$

where $\alpha$ is the initial sorption rate $(\mathrm{mg} / \mathrm{g} \min )$ and $\beta$ is the desorption constant $(\mathrm{g} / \mathrm{mg})$.

In general, high correlation coefficients were obtained by the adjustment models for both $\mathrm{K}^{+}$and $\mathrm{Zn}^{2+}$, regardless of solution concentration. When compared, the values of the correlation coefficients of the pseudo-first-order and pseudo-second-order models are higher for $\mathrm{K}^{+}$than for $\mathrm{Zn}^{2+}$, while the values of the correlation coefficients of the Elovich model are higher for $\mathrm{Zn}^{2+}$ than for $\mathrm{K}^{+}$.

Each of these models is based on specific factors. The pseudo-first-order represents sorption processes that are limited by the sorption capacity of the solid, whereas the pseudo-second-order represents processes limited by chemical variables. However, the Elovich equation better describes the kinetics of adsorption onto heterogeneous surfaces. Table 3 shows that the model that best represents the adsorption process between the zeolite and solute is the pseudo-second-order model. Ho and McKay [74] noted that the limitations of this type of reaction are associated with chemical variables involving valence forces through electron sharing caused by existing covalent forces between the adsorbent and the adsorbate.

\subsection{Column Test Results}

The column experiment was performed in triplicate. The experimental conditions were: particle size $(1.0$ to $2.0 \mathrm{~mm}$ ), column dimensions (height- $151.7 \mathrm{~mm}$; diameter $-97.3 \mathrm{~mm}$; volume $\left.-1.13 \times 10^{-3} \mathrm{~m}^{3}\right), \gamma_{\mathrm{s}}\left(22.87 \mathrm{kN} / \mathrm{m}^{3}\right), \gamma_{\mathrm{d}}\left(10.89 \mathrm{kN} / \mathrm{m}^{3}\right)$, porosity $(0.52)$, void ratio (1.10) and saturated hydraulic conductivity $\left(\mathrm{K}_{\mathrm{sat}}\right)\left(4.61 \times 10^{-5} \mathrm{~m} / \mathrm{s}\right)$. The data obtained from the columns presented a standard deviation of \pm 0.0081 , reflecting that there were no significant variations between the columns. The choice to carry out a column test using zeolite particles with a size range of 1.0 to $2.0 \mathrm{~mm}$ was based on the $K_{\text {sat }}$ values found for the arrangements formed by this size of particle, which are similar to the $\mathrm{K}_{\text {sat }}$ values exhibited by large areas composed of different geological materials and hydrogeological characteristics found in Brazil and other countries.

After completing a cycle composed of contaminated solution percolation and flushing, the breakthrough curves were plotted. The amount of contaminant material that was adsorbed by the zeolite particles, represented by the area above the breakthrough curve, corresponds to stage I, and the amount of material that was desorbed during the flushing process, represented by the area below the curve, corresponds to stage II, as shown in Figure 10 for each cycle. The cation concentration in the effluent increased until the effluent solution (C) reached a concentration equal to that of the influent solution; that is, $\mathrm{C}=\mathrm{C}_{0}$ (equilibrium condition). The amount of $\mathrm{K}^{+}$adsorbed, pore volume quantity, CEC percentage and flushing efficiency of each cycle are shown in Table 4.

The total CEC occupied by the adsorbed $\mathrm{K}^{+}$increased with the progression of the cycles, reaching $90 \%$ after solution percolation and $87 \%$ after the flushing process. This observation implies that the saturation of the zeolite is not achieved in this study because, even when $C / C_{0}=1$, the voids and surface charges available for cationic exchange are not all occupied, which is reflected by the mass of $\mathrm{K}^{+}$that has been adsorbed, demonstrating that there are still spaces available for CEC, even if the concentration of the influent is similar to that of the effluent. 


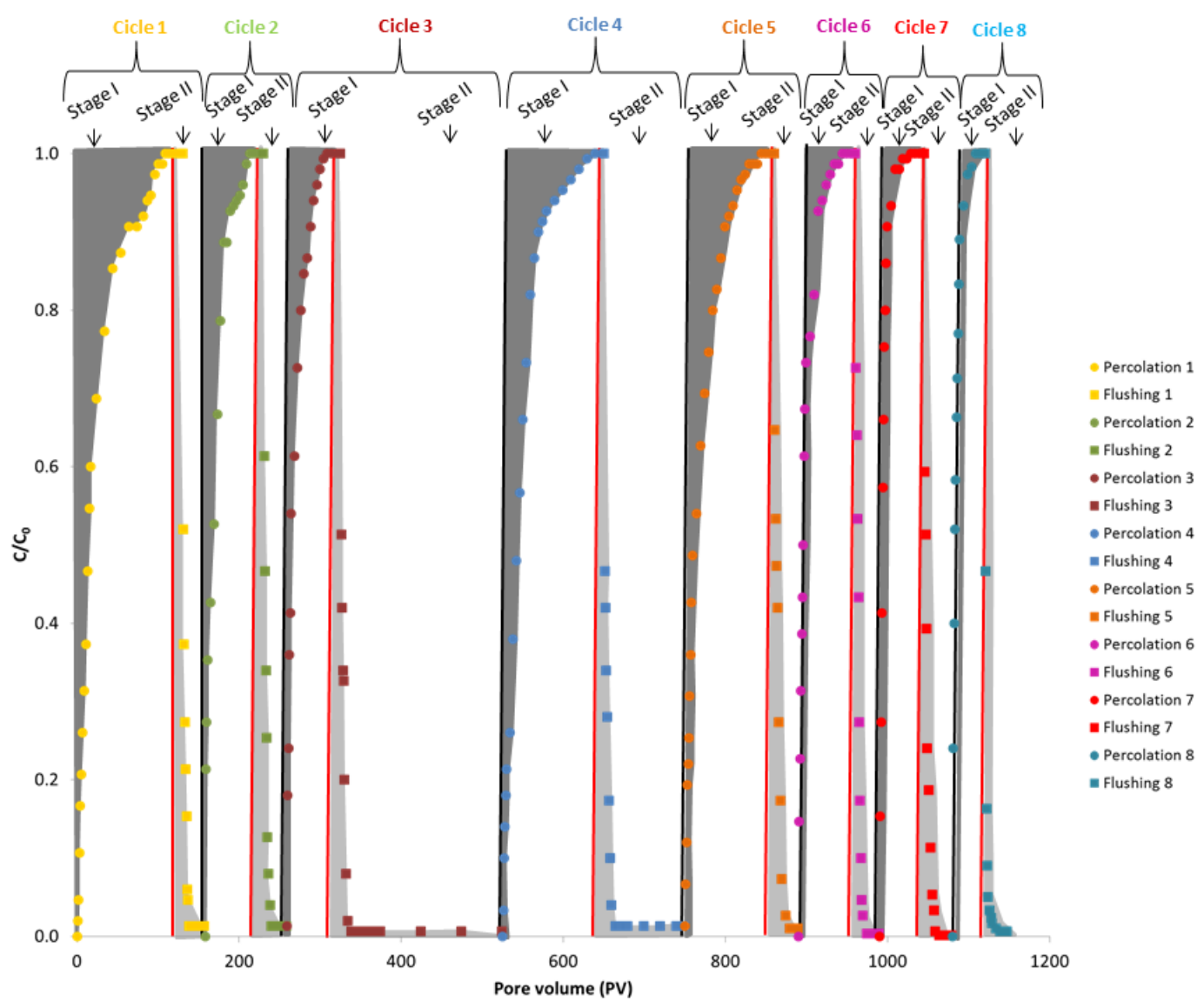

Figure 10. Breakthrough curves obtained from the column test.

This same effect was recorded in zeolites from Cuba and from the municipality of Urupema (South Region of Brazil) [75], which reported that the maximum amount of $\mathrm{Zn}^{2+}$ removed from an aqueous solution was less than the maximum adsorption capacity of the analyzed zeolites. Kitsopoulos [76] suggests that complete saturation of zeolite using $\mathrm{NH}_{4} \mathrm{OAc}$ solution occurs within 12 days. However, this length of time can be considered too long to be feasible for many situations of in-situ and ex-situ groundwater clean-up. Thus, it is inferred that the contact time between the contaminant and zeolite in the experiments was not sufficient for the saturation of the material to occur. Lim et al. [77] also concluded that the longer the contact time is, the greater the amount of contaminant that will be adsorbed. However, the contact time used in the experiments is a viable residence time in natural conditions for the removal of contaminants. Additionally, the column test also revealed that the zeolite showed stable conditions during all steps; the zeolite did not show the formation of any new chemical material due to precipitation or similar processes.

It is possible to observe that, initially, more than 100 pore volumes were required for the effluent concentration to reach the equilibrium condition $\left(C=C_{0}\right)$. However, in the subsequent cycles, the number of pore volumes needed to reach equilibrium conditions decreased as the quantity of water used in the flushing process increased. This finding indicates that the flushing process was not very effective at regenerating the zeolite to the initial conditions, so the adsorption capacity of the zeolite decreased as the number of cycles increased. 
Table 4. Results of the column experiments.

\begin{tabular}{|c|c|c|c|c|c|c|c|c|c|c|c|c|c|c|}
\hline \multirow[b]{2}{*}{ Cycle } & \multicolumn{5}{|c|}{ Contaminated Solution Percolation } & \multicolumn{6}{|c|}{ Flushing Process } & \multicolumn{3}{|c|}{ Final Condition for Cycle } \\
\hline & $\begin{array}{l}\text { Total Pore } \\
\text { Volume } \\
\text { Percolated }\end{array}$ & $\begin{array}{c}\text { Total } \\
\text { Percolated } \\
\text { Volume } \\
\left(\mathrm{cm}^{3}\right)\end{array}$ & $\begin{array}{c}\text { Total } \\
\text { Potassium } \\
\text { Adsorbed } \\
(\mathrm{mg})\end{array}$ & $\begin{array}{c}\text { Adsorbed } \\
\text { Potassium } \\
\text { Rate }(\mathrm{mg} / \mathrm{g})\end{array}$ & $\begin{array}{c}\text { Total CEC } \\
\text { Occupied } \\
\text { at the End } \\
\text { of a Cycle } \\
(\%)\end{array}$ & $\begin{array}{l}\text { Total Void } \\
\text { Volume } \\
\text { Percolated }\end{array}$ & $\begin{array}{c}\text { Total } \\
\text { Percolated } \\
\text { Volume } \\
\left(\mathrm{cm}^{3}\right)\end{array}$ & $\begin{array}{c}\text { Total } \\
\text { Potassium } \\
\text { Desorption } \\
\text { (mg) }\end{array}$ & $\begin{array}{l}\text { Desorption } \\
\text { Potassium } \\
\text { Rate }(\mathrm{mg} / \mathrm{g})\end{array}$ & $\begin{array}{c}\text { CEC } \\
\text { Recovered } \\
\text { by } \\
\text { Flushing } \\
(\%)\end{array}$ & $\begin{array}{c}\text { Flushing } \\
\text { Efficiency } \\
(\%)\end{array}$ & $\begin{array}{l}\text { Potassium } \\
\text { Adsorbed } \\
\quad(\mathrm{mg})\end{array}$ & $\begin{array}{c}\text { Adsorbed } \\
\text { Potassium } \\
\text { Remained after } \\
\text { Flushing } \\
(\mathrm{mg} / \mathrm{g})\end{array}$ & $\begin{array}{c}\text { Total CEC } \\
\text { Occupied } \\
\text { after } \\
\text { Flushing } \\
(\%)\end{array}$ \\
\hline 1 & 129 & $81,779.5$ & $22,251.65$ & 19.05 & 27.14 & 28 & $17,750.6$ & 2282.22 & 1.95 & 2.79 & 11.43 & $19,969.43$ & 17.09 & 24.35 \\
\hline 2 & 72 & $45,644.4$ & 9804.04 & 8.40 & 36.31 & 29 & $18,384.5$ & 2567.50 & 2.20 & 3.13 & 9.44 & $27,205.96$ & 23.29 & 33.18 \\
\hline 3 & 64 & $40,572.8$ & 8082.86 & 6.92 & 43.04 & 200 & $126,790.0$ & 3518.42 & 3.01 & 4.29 & 11.07 & $31,770.40$ & 27.20 & 38.75 \\
\hline 4 & 125 & $79,243.8$ & $18,733.22$ & 16.07 & 61.59 & 100 & $63,395.0$ & 3518.42 & 3.01 & 4.29 & 7.49 & $46,985.20$ & 40.23 & 57.30 \\
\hline 5 & 110 & $69,734.5$ & $16,707.75$ & 14.31 & 77.68 & 30 & $19,018.5$ & 3518.42 & 3.01 & 4.29 & 5.85 & $60,174.53$ & 51.52 & 73.39 \\
\hline 6 & 70 & $44,376.5$ & 7797.59 & 6.68 & 82.90 & 30 & $19,018.5$ & 3328.24 & 2.85 & 4.06 & 5.15 & $64,643.88$ & 55.35 & 78.84 \\
\hline 7 & 55 & $34,867.3$ & 4374.26 & 3.75 & 84.18 & 35 & $22,188.3$ & 2852.78 & 2.44 & 3.48 & 4.31 & $66,165.36$ & 56.65 & 80.70 \\
\hline 8 & 40 & $25,358.0$ & 8177.96 & 7.00 & 90.67 & 30 & $19,018.5$ & 2852.78 & 2.44 & 3.48 & 3.99 & $71,490.54$ & 61.21 & 87.19 \\
\hline
\end{tabular}


The $\mathrm{pH}$ range was from 5 to 7 during the contaminant solution percolation and flushing process. The zeolite exhibits maximum adsorption capacity results at a pH between 5 and 6 [14,78-80]. The water had a $\mathrm{pH}$ in the range of 6.8 to 7.2 , which explains the increase in the $\mathrm{pH}$ during the flushing process. The temperature was maintained at approximately $21 \pm 2{ }^{\circ} \mathrm{C}$ during the experiment. The EC varied from 4 to $6 \mathrm{mS}$ during the percolation of the potassium solution. In contrast, when in contact with water during the flushing process, the EC values decreased markedly, reaching approximately 0.003 $\mathrm{mS}$. The contaminant transport parameters for $\mathrm{K}^{+}$in the column test are as follows: retardation factor $\left(R_{d}\right)=24.9$, hydrodynamic dispersion coefficient $\left(D_{h}\right)=1.32 \times 10^{-2} \mathrm{~cm}^{2} / \mathrm{s}$ and dispersivity coefficient $(\alpha)=1.42$.

\subsection{Flushing Results}

The flushing process was carried out to analyze the potential to clean-up zeolite through reaction with water flowing through the column. An additional test was performed to analyze the potential to clean-up the zeolite through reaction with the same amount of water. Thus, the mass of potassium removed from the zeolite structure in the column during the flushing process can be related to the total CEC of the zeolite (as shown in Table 4), which indicates the flushing efficiency of the material.

In general, the flushing process was executed at a flow rate of $3.91 \times 10^{-5} \mathrm{~m} / \mathrm{s}$ until the outlet solution showed equilibrium. To investigate the influence of the amount of water passing through the column, the pore volume quantity was alternated in some cycles. Initially, the flushing was performed until the outlet solution reached equilibrium, which was equivalent to approximately 10 pore volumes (cycle 1). After this process, the quantity of cation adsorbed in the subsequent cycle is low, indicating that only an external washing of the zeolite particles occurred. Then, the flushing was continued even after equilibrium was reached, as observed in cycles 3 and 4; thus, a greater amount of water percolated through the column, and the contact time between the water and particle surfaces was longer. It is believed that during a long flushing process, the longer contact time between the zeolite and water makes it possible to wash the external surfaces of the zeolite particles and to desorb ions in voids, resulting in a larger number of sites available for subsequent adsorption processes, as confirmed in cycles 4 and 5. It is worth mentioning that when considering the duration of the flushing process, the water quantity and contact time should also be considered. In almost all flushing curves obtained, the effluent concentration showed equilibrium after the percolation of only 10 initial pore volumes. However, even when showing a stabilized concentration in the effluent, the amount of contaminant retained in the zeolite structure increased with an increasing number of cycles, demonstrating the low efficiency of the flushing process.

The additional test to analyze desorption reactions was carried out over 40 days. In the first part, the adsorption process developed until the concentration of $\mathrm{K}^{+}$stabilized in the contaminated solution; then, the zeolite sample was put in contact with water until the $\mathrm{K}^{+}$concentration remained stable among several measurements. The results obtained in both phases of this experiment are shown in Figure 11. The adsorption graph corresponds to the first stage where zeolite particles were saturated with the $\mathrm{K}^{+}$ion solution. The desorption graph corresponds to the mass of $\mathrm{K}^{+}$ions that left the zeolite structure by reaction with water. Through this experiment, it can be observed that the clean-up efficiency of the zeolite is directly linked to the contact time between the water and the solid material, considering that the volume of water remained constant in this test. Similarly to the adsorption process, the desorption of zeolite consists of two phases, a first phase that occurs rapidly and a secondary phase that occurs at a slower rate but continuously. The presented curve clearly shows that during the 40 days of the test, small amounts of $\mathrm{K}^{+}$continued to leave the structure of the zeolite. 

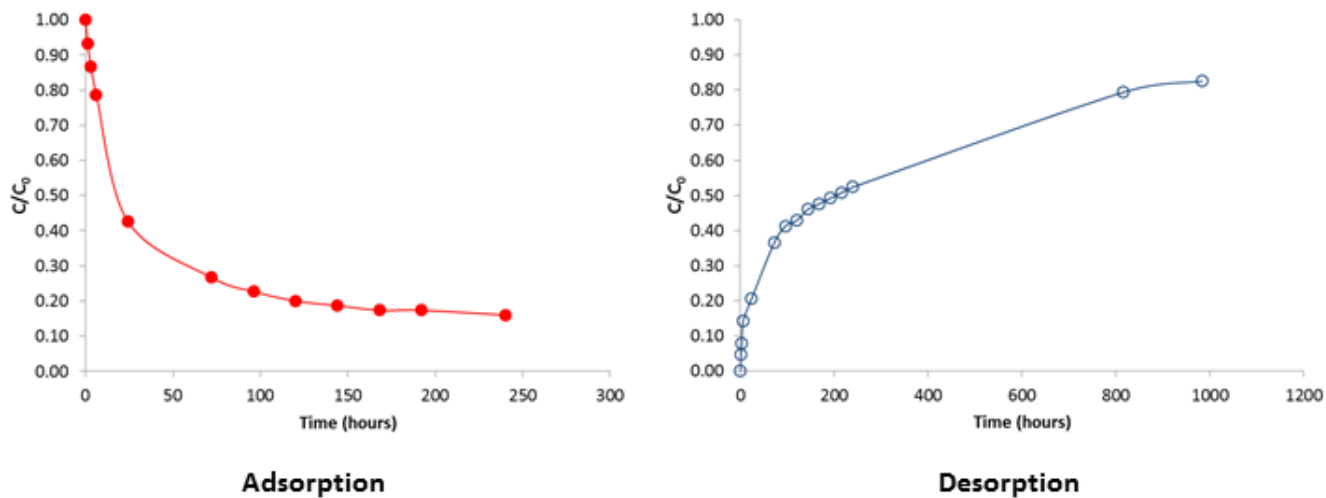

Figure 11. Adsorption and desorption processes of $\mathrm{K}^{+}$ions on zeolite.

\subsection{Chemical Characterization after Sorption Processes}

Table 5 shows the results of the XRF chemical analysis obtained for the zeolite samples that were previously exposed to the $200 \mathrm{mg} / \mathrm{L} \mathrm{K}^{+}$contaminant solution. The same table presents the chemical characterization data of the natural sample, that is, before the exposure to the contaminant solution, to enable the comparison between these data sets.

Table 5. Chemical composition of the zeolite before and after sorption processes.

\begin{tabular}{ccc}
\hline \multirow{2}{*}{ Elements } & Initial & Final \\
\cline { 2 - 3 } & \multicolumn{2}{c}{$\mathbf{1 0 0 \%}$ Mass/Mass } \\
\hline $\mathrm{Mg}$ & 0.716 & 0.423 \\
$\mathrm{Al}$ & 9.735 & 8.433 \\
$\mathrm{Si}$ & 72.47 & 70.066 \\
$\mathrm{~K}$ & 4.331 & 8.113 \\
$\mathrm{Ca}$ & 8.489 & 6.423 \\
$\mathrm{Ti}$ & 0.384 & 0.380 \\
$\mathrm{Fe}$ & 3.488 & 3.338 \\
$\mathrm{Zn}$ & 0.023 & 0.021 \\
$\mathrm{Ba}$ & 0.364 & 0.341 \\
$\mathrm{Cl}$ & - & 2.462 \\
\hline
\end{tabular}

From the data presented, it can be seen that the contamination of zeolite did not significantly change the fundamental chemical composition of this mineral ( $\mathrm{Si}$ and $\mathrm{Al}$ ), which is supported by the fact that these ions exist in the crystalline structure of the zeolite and cannot be replaced. However, there were significant changes in the compensation ions $\left(\mathrm{Mg}^{2+}\right.$ and $\left.\mathrm{Ca}^{2+}\right)$. It is worth mentioning that $\mathrm{K}^{+}$is also a zeolite compensation ion, but as it is the focus of this research, it is not treated as such.

An analysis of the exchanges revealed that the most significant changes were for $\mathrm{Ca}^{2+}$ ions, followed by $\mathrm{Mg}^{2+}$ ions. In general, the zeolite exchanged some of these ions for the $\mathrm{K}^{+}$ions that were previously in solution. This observation is supported by the zeolite affinity, which, according to Ames [81], obeys the following order: $\mathrm{Cs}^{+}>\mathrm{Rb}^{+}>\mathrm{K}^{+}>\mathrm{Li}^{+}>\mathrm{NH}_{4}{ }^{+}>\mathrm{Na}^{+}>\mathrm{Ba}^{2+}>\mathrm{Ca}^{2+}$. According to Karagad [82], when dealing with compensation ions, the order of selectivity displayed by zeolites is $\mathrm{K}^{+}>\mathrm{Na}^{+}>\mathrm{Ca}^{2+}>\mathrm{Mg}^{2+}$.

\section{Conclusions}

The analyzed zeolite is composed predominantly of the clinoptilolite species and has an average specific weight of $22.8 \mathrm{kN} / \mathrm{m}^{3}$, a Si/Al ratio of 6.8 , a total CEC of $180 \mathrm{cmol}_{\mathrm{c}} / \mathrm{kg}$ and a variable external CEC depending on particle size ( 2 to $18 \mathrm{cmol}_{\mathrm{c}} / \mathrm{kg}$ ). The particle sizes between 0.4 and $3.0 \mathrm{~mm}$ enable different volumetric arrangements with specific apparent dry weight ranging from 10 to $11 \mathrm{kN} / \mathrm{m}^{3}$ 
and saturated hydraulic conductivity values between $1.11 \times 10^{-5}$ and $2.95 \times 10^{-4} \mathrm{~m} / \mathrm{s}$. These aspects provide a high potential for using this material in a variety of natural geological and hydrogeological conditions. The $\mathrm{K}^{+}$adsorption data are effectively represented by the Langmuir isotherm $(\alpha=0.0053 \mathrm{l} / \mathrm{g}$; $\left.\beta=24.69 \mathrm{mg} / \mathrm{g} ; \mathrm{r}^{2}=0.997\right)$, and the adsorption kinetics are best represented by the pseudo-second-order reaction model $\left(\mathrm{k}_{2}=0.009\right.$ and $\left.\mathrm{r}^{2}=0.999\right)$. The contaminant transport parameters for $\mathrm{K}^{+}\left(\mathrm{R}_{\mathrm{d}}=24.9\right.$; $D_{\mathrm{h}}=1.32 \times 10^{-2} \mathrm{~cm}^{2} / \mathrm{s}$ and $\left.\alpha=1.42\right)$ indicate that the zeolite is resistant to the dispersion of the contaminant in the groundwater, which is a positive characteristic for use in a PRB. Breakthrough curves obtained from column tests demonstrated that the material has a high capacity to adsorb $\mathrm{K}^{+}$ions and a long-term operating life in a PRB. However, the flushing process onto the zeolite is not significant because it reaches only the external surface of the particles. Several factors may have influenced this result, but it is believed that the time and conditions of contact between the particle surfaces and ion solution, as well as the water interaction conditions, were the determining parameters. For this reason, based on the study results, the use of zeolite is recommended for systems where it can be replaced after its complete saturation. Such replacement is not infeasible due to the low economic value of the zeolite. In addition, the residue can be used as raw material for construction or other processes.

Author Contributions: Data curation, L.C.C.R. and L.V.Z.; Funding acquisition, L.V.Z.; Investigation, L.C.C.R.; Supervision, L.V.Z.; Writing-original draft, L.C.C.R.; Writing-review \& editing, L.V.Z. All authors have read and agreed to the published version of the manuscript.

Funding: This research was funded by São Paulo Research Foundation (FAPESP), grant number 02162-0/2014 and the National Council for Scientific and Technological Development (CNPQ) for the scholarship during the research. The APC was funded by Universidade de São Paulo".

Conflicts of Interest: The authors declare no conflict of interest. The funders had no role in the design of the study; in the collection, analyses, or interpretation of data; in the writing of the manuscript, or in the decision to publish the results.

\section{References}

1. Mizukawa, A.; Filippe, T.C.; Peixoto, L.O.M.; Scipioni, B.; Leonardi, I.R.; De Azevedo, J.C.R. Caffeine as a chemical tracer for contamination of urban rivers. RBRH 2019, 24, 29. [CrossRef]

2. Sollecito, F.; Vitone, C.; Miccoli, D.; Plötze, M.; Puzrin, A.M.; Cotecchia, F. Marine Sediments from a Contaminated Site: Geotechnical Properties and Chemo-Mechanical Coupling Processes. Geosciences 2019, 9 , 333. [CrossRef]

3. WWAP- World Water Assessment Programme. The United Nations World Water Development Report 2015: Water for a Sustainable World. Paris: United Nations World Water Assessment Programme, UNESCO, 2015. Available online: http://unesdoc.unesco.org/images/0023/002318/231823E.pdf (accessed on 5 September 2019).

4. Manikandan, S.; Chidambaram, S.; Prasanna, M.V.; Ganayat, R.R. Assessment of Heavy Metals Pollution and Stable Isotopic Signatures in Hard Rock Aquifers of Krishnagiri District, South India. Geosciences 2019, 9 , 200. [CrossRef]

5. Mateo-Sagasta, J.; Zadeh, S.M.; Turral, H. Water Pollution from Agriculture: A Global Review; FAO-Food and Agriculture Organization of the United Nations and the IWMI-International Water Management Institute: Colombo, Sri Lanka, 2017.

6. Mathews, B.W.; Sollenberger, L.E.; Nair, V.D.; Staples, C.R. Impact of Grazing Management on Soil Nitrogen, Phosphorus, Potassium, and Sulfur Distribution. J. Environ. Qual. 1994, 23, 1006-1013. [CrossRef]

7. Bertol, I.; Engel, F.; Mafra, A.; Bertol, O.; Ritter, S. Phosphorus, potassium and organic carbon concentrations in runoff water and sediments under different soil tillage systems during soybean growth. Soil Tillage Res. 2007, 94, 142-150. [CrossRef]

8. Wahba, M.M.; Aziz, A.M.; Zaghloul, A.M. Evaluation of Kinetic Approach in Describing Potassium Bioavailability. Am. J. Heterocycl. Chem. 2017, 3, 78. [CrossRef]

9. Dimirkou, A. Uptake of Zn2+ ions by a fully iron-exchanged clinoptilolite. Case study of heavily contaminated drinking water samples. Water. Res. 2007, 41, 2763-2773. [CrossRef] 
10. Nagajyoti, P.C.; Lee, K.D.; Sreekanth, T.V.M. Heavy metals, occurrence and toxicity for plants: A review. Environ. Chem. Lett. 2010, 8, 199-216. [CrossRef]

11. He, F.; Gao, J.; Pierce, E.; Strong, P.J.; Wang, H.; Liang, L. In situ remediation technologies for mercury-contaminated soil. Environ. Sci. Pollut. Res. 2015, 22, 8124-8147. [CrossRef]

12. Barragán, P.P.; Macedo, M.G.M.; Olguín, M.T. Cadmium sorption by sodium and thiourea-modified zeolite-rich tuffs. J. Environ. Sci. 2017, 52, 39-48. [CrossRef]

13. Yin, S.; Herath, G.; Heng, S.; Kalpage, S. Using Permeable Reactive Barriers to Remediate Heavy Metal-Contaminated Groundwater through a Laboratory Column Experiment. Am. J. Environ. Sci. 2017, 13, 103-115. [CrossRef]

14. Kong, X.; Huang, G.; Han, Z.; Xu, Y.; Zhu, M.; Zhang, Z. Evaluation of zeolite-supported microscale zero-valent iron as a potential adsorbent for $\mathrm{Cd}^{2+}$ and $\mathrm{Pb}^{2+}$ removal in permeable reactive barriers. Environ. Sci. Pollut. Res. 2017, 24, 13837-13844. [CrossRef] [PubMed]

15. Blanco, M.; Martinez, A.; Marcaide, A.; Aranzabe, E. Heterogeneous Fenton Catalyst for the Efficient Removal of Azo Dyes in Water. Am. J. Anal. Chem. 2014, 5, 490-499. [CrossRef]

16. Shabalala, A.N.; Ekolu, S.O.; Diop, S.; Solomon, F. Pervious concrete reactive barrier for removal of heavy metals from acid mine drainage—column study. J. Hazard. Mater. 2017, 323, 641-653. [CrossRef]

17. Ugrina, M.; Medvidović, N.V.; Perić, J.; Trgo, M. A study of kinetics and successive sorption/desorption of Zn and Cd uptake onto iron-modified zeolite. Clay Miner. 2015, 50, 117-132. [CrossRef]

18. Sun, Y.; Fang, Q.; Dong, J.; Cheng, X.; Xu, J. Removal of fluoride from drinking water by natural stilbite zeolite modified with Fe(III). Desalination 2011, 277, 121-127. [CrossRef]

19. Dowson, G.R.M.; Dimitriou, I.; Owen, R.E.; Reed, D.G.; Allen, R.W.K.; Styring, P. Kinetic and economic analysis of reactive capture of dilute carbon dioxide with Grignard reagents. Faraday Discuss. 2015, 183, 47-65. [CrossRef]

20. Obiri-Nyarko, F.; Mesa, S.J.G.; Malina, G. An overview of permeable reactive barriers for in situ sustainable groundwater remediation. Chemosphere 2014, 111, 243-259. [CrossRef]

21. Powell, R.M.; Blowes, D.W.; Gillham, R.W.; Schultz, D.; Sivavec, T.; Puls, R.W.; Vogan, J.L.; Powell, P.D.; Landis, R. Permeable Reactive Barrier Technologies for Contaminant Remediation; Report EPA/600//R-98/125; U.S. Environmental Protection Agency: Washington, DC, USA, 1998.

22. Chen, H.; Park, E.; Hu, C. A design solution of PRB with multispecies transport based on a multi-domain system. Environ. Earth Sci. 2018, 77, 630. [CrossRef]

23. Mesa, S.J.G.; Malina, G. Screening reactive materials for a permeable barrier to treat TCE-contaminated groundwater: Laboratory studies. Environ. Earth Sci. 2016, 75, 772. [CrossRef]

24. Luo, X.; Liu, H.; Huang, G.; Li, Y.; Zhao, Y.; Li, X. Remediation of arsenic-contaminated groundwater using media-injected permeable reactive barriers with a modified montmorillonite: Sand tank studies. Environ. Sci. Pollut. Res. 2016, 23, 870-877. [CrossRef] [PubMed]

25. Salgado-Gómez, N.; Macedo-Miranda, M.; Olguín, M. Chromium VI adsorption from sodium chromate and potassium dichromate aqueous systems by hexadecyltrimethylammonium-modified zeolite-rich tuff. Appl. Clay Sci. 2014, 95, 197-204. [CrossRef]

26. Dalal, U.; Reddy, S.N. A novel nano zero-valentironbiomaterial for chromium (Cr6+ to Cr3+) reduction. Environ. Sci. Pollut. Res. 2019, 26, 10631-10640. [CrossRef] [PubMed]

27. Bibiano-Cruz, L.; Garfias, J.; Salas-García, J.; Martel, R.; Llanos, H. Batch and column test analyses for hardness removal using natural and homoionic clinoptilolite: Breakthrough experiments and modeling. Sustain. Water Resour. Manag. 2016, 2, 183-197. [CrossRef]

28. Buenaño, X.; Canoira, L.; Sánchez, D.M.; Costafreda, J. Zeolitic tuffs for acid mine drainage (AMD) treatment in Ecuador: Breakthrough curves for $\mathrm{Mn}^{2+}, \mathrm{Cd}^{2+}, \mathrm{Cr}^{3+}, \mathrm{Zn}^{2+}$, and $\mathrm{Al}^{3+}$. Environ. Sci. Pollut. Res. 2017, 24, 6794-6806. [CrossRef]

29. Kim, S.; Durand, P.; Roques-Carmes, T.; Eastoe, J.; Pasc, A. Metallo-Solid Lipid Nanoparticles as Colloidal Tools for Meso-Macroporous Supported Catalysts. Langmuir 2015, 31, 1842-1849. [CrossRef]

30. Wang, Y.; Pleasant, S.; Jain, P.; Powell, J.; Townsend, T. Calcium carbonate-based permeable reactive barriers for iron and manganese groundwater remediation at landfills. Waste Manag. 2016, 53, 128-135. [CrossRef]

31. Lee, S.M.; Lalhmunsianma; Tiwari, D. Sericite in the remediation of $\mathrm{Cd}(\mathrm{II})^{-}$and $\mathrm{Mn}(\mathrm{II})^{-}$contaminated waters: Batch and column studies. Environ. Sci. Pollut. Res. 2014, 21, 3686-3696. [CrossRef] 
32. Hong, C.S.; Shackelford, C.D. Long-Term Column Testing of Zeolite-Amended Backfills. I: Testing Methodology and Chemical Compatibility. J. Geotech. Geoenviron. Eng. 2017, 143, 04017050. [CrossRef]

33. Li, S.; Huang, G.; Kong, X.; Yang, Y.; Liu, F.; Hou, G.; Chen, H. Ammonium removal from groundwater using a zeolite permeable reactive barrier: A pilot-scale demonstration. Water Sci. Technol. 2014, 70, 1540-1547. [CrossRef]

34. Mahmoodi, N.M.; Saffar-Dastgerdi, M.H. Zeolite nanoparticle as a superior adsorbent with high capacity: Synthesis, surface modification and pollutant adsorption ability from wastewater. Microchem. J. 2019, 145, 74-83. [CrossRef]

35. Nikashina, V.A.; Serova, I.B.; Kats, E.M.; Tokmachev, M.G.; Toropchenova, E.S.; Zhilkina, A.V.; Kuz'Mina, T.G.; Bulenova, K. Permeable reactive barriers based on natural zeolites from Kazakhstan in solving ecological problems: Mathematical model and simulation. Geochem. Int. 2017, 55, 38-46. [CrossRef]

36. Simsek, E.B.; Tuna, A.O.A.; Beker, U. A statistical approach for arsenic adsorption onto Turkey clinoptilolite. Environ. Sci. Pollut. Res. 2015, 22, 3249-3256. [CrossRef] [PubMed]

37. Statham, T.M.; Stark, S.C.; Snape, I.; Stevens, G.W.; Mumford, K.A. A permeable reactive barrier (PRB) media sequence for the remediation of heavy metal and hydrocarbon contaminated water: A field assessment at Casey Station, Antarctica. Chemosphere 2016, 147, 368-375. [CrossRef]

38. Jovanovic, M.; Rajic, N.; Obradovic, B. Novel kinetic model of the removal of divalent heavy metal ions from aqueous solutions by natural clinoptilolite. J. Hazard. Mater. 2012, 233, 57-64. [CrossRef]

39. Zanin, E.; Scapinello, J.; De Oliveira, M.; Rambo, C.L.; Franscescon, F.; Freitas, L.; De Mello, J.M.M.; Fiori, M.A.; Oliveira, J.; Magro, J.D. Adsorption of heavy metals from wastewater graphic industry using clinoptilolite zeolite as adsorbent. Process. Saf. Environ. Prot. 2017, 105, 194-200. [CrossRef]

40. Putra, H.; Yasuhara, H.; Kinoshita, N. Applicability of Natural Zeolite for NH-Forms Removal in Enzyme-Mediated Calcite Precipitation Technique. Geosciences 2017, 7, 61. [CrossRef]

41. Hao, X.; Hou, G.; Zheng, P.; Liu, R.; Liu, C. H2S in-situ removal from biogas using a tubular zeolite/TiO2 photocatalytic reactor and the improvement on methane production. Chem. Eng. J. 2016, 294, 105-110. [CrossRef]

42. Nasonova, A.; Kim, K.-S. Effects of TiO2 coating on zeolite particles for $\mathrm{NO}$ and $\mathrm{SO} 2$ removal by dielectric barrier discharge process. Catal. Today 2013, 211, 90-95. [CrossRef]

43. Arimi, M.M. Modified natural zeolite as heterogeneous Fenton catalyst in treatment of recalcitrants in industrial effluent. Prog. Nat. Sci. 2017, 27, 275-282. [CrossRef]

44. Ambrozova, P.; Kynicky, J.; Urubek, T.; Nguyen, V.D. Synthesis and Modification of Clinoptilolite. Molecules 2017, 22, 1107. [CrossRef]

45. Koyama, K.; Takéuchi, Y. Clinoptilolite: The distribution of potassium atoms and its role in thermal stability. Zeitschrift für Kristallographie-Crystalline Materials 1977, 145, 216-239. [CrossRef]

46. Aharoni, C.; Sparks, D.L. Kinetics of Soil Chemical Reactions-A Theoretical Treatment. Rates Soil Chem. Processes 1991, 27, 1-18. [CrossRef]

47. Nguyen, M.L.; Tanner, C.C. Ammonium removal from wastewaters using natural New Zealand zeolites. $N$. Z. J. Agric. Res. 1998, 41, 427-446. [CrossRef]

48. Olah, J.; Papp, J.; Meszaros-Kis, A.; Muscy, G.; Kallo, D. Removal of suspended solids, phosphate and ammonium ions from communal sewage using clinoptilolite derivatives. In Occurrence, Properties and Utilization of Natural Zeolites; Kalló, D., Sherry, H.S., Eds.; Akademiai Kiado: Budapeste, Hungary, 1988; pp. 511-520.

49. Rodríguez, G.; Brito-Rojas, A.; Countín-Correa, D. Sedimentary Zeolite Deposits in Cuba. In Zeolites; International Zeolite Association (IZA): La Habana, Cuba, 2014; Available online: http://www.iza-online.org/ natural/Catalog/Cuba.pdf (accessed on 8 October 2019).

50. Brazilian Association of Technical Standards. NBR 7181: Soil_Particle Size Analysis; The Brazilian Association of Technical Standards: Rio de Janeiro, Brazil, 1984.

51. Brazilian Association of Technical Standards. NBR 6508: Soil Grains Passing through the Sieve $4.8 \mathrm{~mm}$ : Determination of Specific Mass: Test Method; The Brazilian Association of Technical Standards: Rio de Janeiro, Brazil, 1984.

52. Brazilian Association of Technical Standards. NBR 12004: Solo-Determination of the Maximum Void Index of Non-Cohesive Soils; The Brazilian Association of Technical Standards: Rio de Janeiro, Brazil, 1990. 
53. Brazilian Association of Technical Standards. NBR 12051: Solo-Determination of the Minimum Void Index of Non-Cohesive Soils; The Brazilian Association of Technical Standards: Rio de Janeiro, Brazil, 1991.

54. Chapman, H.D. Cation Exchange Capacity. In Methods of Soil Analysis; Black, C.A., Ed.; American Society of Agronomy: Madison, WI, USA, 1965; pp. 891-901.

55. Choo, K.Y.; Bai, K. The effect of the mineralogical composition of various bentonites on CEC values determined by three different analytical methods. Appl. Clay Sci. 2016, 126, 153-159. [CrossRef]

56. Zhou, L.; Boyd, C.E. Total ammonia nitrogen removal from aqueous solutions by the natural zeolite, mordenite: A laboratory test and experimental study. Aquaculture 2014, 432, 252-257. [CrossRef]

57. Pejon, O.J. Regional Geotechnical Mapping of the Leaf of Piracicaba-SP (Scale 1: 100.000) Study of Methodological Aspects of Characterization and Presentation of Attributes. Ph.D. Thesis, São Carlos School of Engineering, University of São Paulo, São Carlos, Brazil, 1992.

58. Roy, W.; Krapac, I.; Chou, S.; Griffin, R. Batch-Type Procedures for Estimating Soil Adsorption of Chemicals; United States Environmental Protection Agency: Washington, DC, USA, 1992; EPA/530/SW-87/006F.

59. Shackelford, C.D. Critical Concepts for Column Testing. J. Geotech. Eng. 1994, 120, 1804-1828. [CrossRef]

60. Shackelford, C.D. Cumulative Mass Approach for Column Testing. J. Geotech. Eng. 1995, 121, 696-703. [CrossRef]

61. Ming, D.W.; Mumpton, F.A. Zeolites in Soils. In Minerals in Soil Environments; Soil Science Society of America: Madison, WI, USA, 1989; pp. 873-907.

62. Rodriguez-Fuentes, G.; Ruiz-Salvador, A.R.; Mir, M.; Picazo, O.; Quintana, G.; Delgado, M. Thermal and cation influence on ir vibrations of modified natural clinoptilolite. Microporous Mesoporous Mater. 1998, 20, 269-281. [CrossRef]

63. Coombs, D.S.; Alberti, A.; Armbruster, T.; Artioli, G.; Colella, C.; Galli, E.; Grice, J.D.; Liebau, F.; Mandarino, J.A.; Minato, H.; et al. Recommended nomenclature for zeolite minerals: Report of the subcommittee on zeolites of the International Mineralogical Association, Comission on New Minerals and Mineral Names. Mineral. Mag. 1997, 35, 1571-1606.

64. Wasielewski, S.; Rott, E.; Minke, R.; Steinmetz, H. Evaluation of Different Clinoptilolite Zeolites as Adsorbent for Ammonium Removal from Highly Concentrated Synthetic Wastewater. Water 2018, 10, 584. [CrossRef]

65. Oliveira, S.A. Study of Heavy Metal Adsorption in Zeolites for use in Reactive Barrier. Master's Thesis, Federal University of Rio de Janeiro, Rio de Janeiro, RJ, Brazil, 2011; p. 220f.

66. Barros, M.A.S.D. Removal of $\mathrm{Cr}^{3+}$ of Industrial and Synthetic Effluents by Naturally Action of Clinoptilolite. Master's Thesis, Maringá State University, Maringá, Brazil, 1996; p. 140f.

67. Amini, N.; Soleimani, M.; Mirghaffari, N. Photocatalytic removal of SO2 using natural zeolite modified by $\mathrm{TiO} 2$ and polyoxypropylene surfactant. Environ. Sci. Pollut. Res. 2018, 26, 16877-16886. [CrossRef] [PubMed]

68. Jaskunas, A.; Subacius, B.; Slinksiene, R. Adsorption of potassium ions on natural zeolite: Kinetic and equilibrium studies. Chemija 2015, 26, 69-78.

69. Panayotova, M.; Velikov, B. Kinetics of heavy metal ions removal by use of natural zeolite. J. Environ. Sci. Heal. Part A 2002, 37, 139-147. [CrossRef]

70. Giles, C.H.; MacEwan, T.H.; Nakhwa, S.N.; Smith, D. Studies in adsorption. Part XI. A system of classification of solution adsorption isotherms, and its use in diagnosis of adsorption mechanisms and in measurement of specific surface areas of solids. J. Chem. Soc. 1960, 3973. [CrossRef]

71. Shaban, M.; Hassouna, M.E.M.; Nasief, F.M.; Abukhadra, M.R. Adsorption properties of kaolinite-based nanocomposites for Fe and Mn pollutants from aqueous solutions and raw ground water: Kinetics and equilibrium studies. Environ. Sci. Pollut. Res. 2017, 24, 22954-22966. [CrossRef]

72. Allen, S.J.; Gan, Q.; Matthews, R.; Johnson, P.A. Comparison of optimized isotherm models for basic dye adsorption by kudzu. Bioresour. Technol. 2003, 88, 143-152. [CrossRef]

73. Bueno, B.Y.M. Removal of $\mathrm{Pb}, \mathrm{Cr}$ and $\mathrm{Cu}$ Removal by Combined Biosorption/Bioflotting Process Using Rhodococcus Opacus Strain. Ph.D. Thesis, Pontifical Catholic University of Rio de Janeiro, Rio de Janeiro, Brazil, 2007; p. 172f.

74. Ho, Y.; McKay, G. A Comparison of Chemisorption Kinetic Models Applied to Pollutant Removal on Various Sorbents. Process. Saf. Environ. Prot. 1998, 76, 332-340. [CrossRef]

75. Correia, T.A.; Campos, M.L.; Almeida, J.A.; Miquelluti, D.J.; Souza, M.C. Characterization of zeolites from Urupema, SC, and their ability to remove $\mathrm{Cu}^{2+}$ from aqueous solutions. Revista de Ciências Agroveterinárias 2010, 9, 29-38. 
76. Kitsopoulos, K.P. Cation-Exchange Capacity (CEC) of Zeolitic Volcaniclastic Materials: Applicability of the Ammonium Acetate Saturation (AMAS) Method. Clays Clay Miner. 1999, 47, 688-696. [CrossRef]

77. Lim, S.-F.; Lee, A.Y.W. Kinetic study on removal of heavy metal ions from aqueous solution by using soil. Environ. Sci. Pollut. Res. 2015, 22, 10144-10158. [CrossRef]

78. Fu, R.; Yang, Y.; Xu, Z.; Zhang, X.; Guo, X.; Bi, D. The removal of chromium (VI) and lead (II) from groundwater using sepiolite-supported nanoscale zero-valent iron (S-NZVI). Chemosphere 2015, 138, 726-734. [CrossRef] [PubMed]

79. Huang, T.; Li, N.; Kexiang, L.; Zhang, Y. Heavy metal removal from MSWI fly ash by electrokinetic remediation coupled with a permeable activated charcoal reactive barrier. Sci. Rep. 2015, 5, 15412. [CrossRef] [PubMed]

80. Liu, Y.; Mou, H.; Chen, L.; Mirza, Z.A.; Liu, L. Cr(VI)-contaminated groundwater remediation with simulated permeable reactive barrier (PRB) filled with natural pyrite as reactive material: Environmental factors and effectiveness. J. Hazard. Mater. 2015, 298, 83-90. [CrossRef] [PubMed]

81. Ames, L.L. The cation sieve properties of clinoptilolite. Am Miner. 1960, 45, 689-700.

82. Karadag, D.; Koç, Y.; Turan, M.; Armagan, B.; Armaǧan, B. Removal of ammonium ion from aqueous solution using natural Turkish clinoptilolite. J. Hazard. Mater. 2006, 136, 604-609. [CrossRef]

(C) 2020 by the authors. Licensee MDPI, Basel, Switzerland. This article is an open access article distributed under the terms and conditions of the Creative Commons Attribution (CC BY) license (http://creativecommons.org/licenses/by/4.0/). 